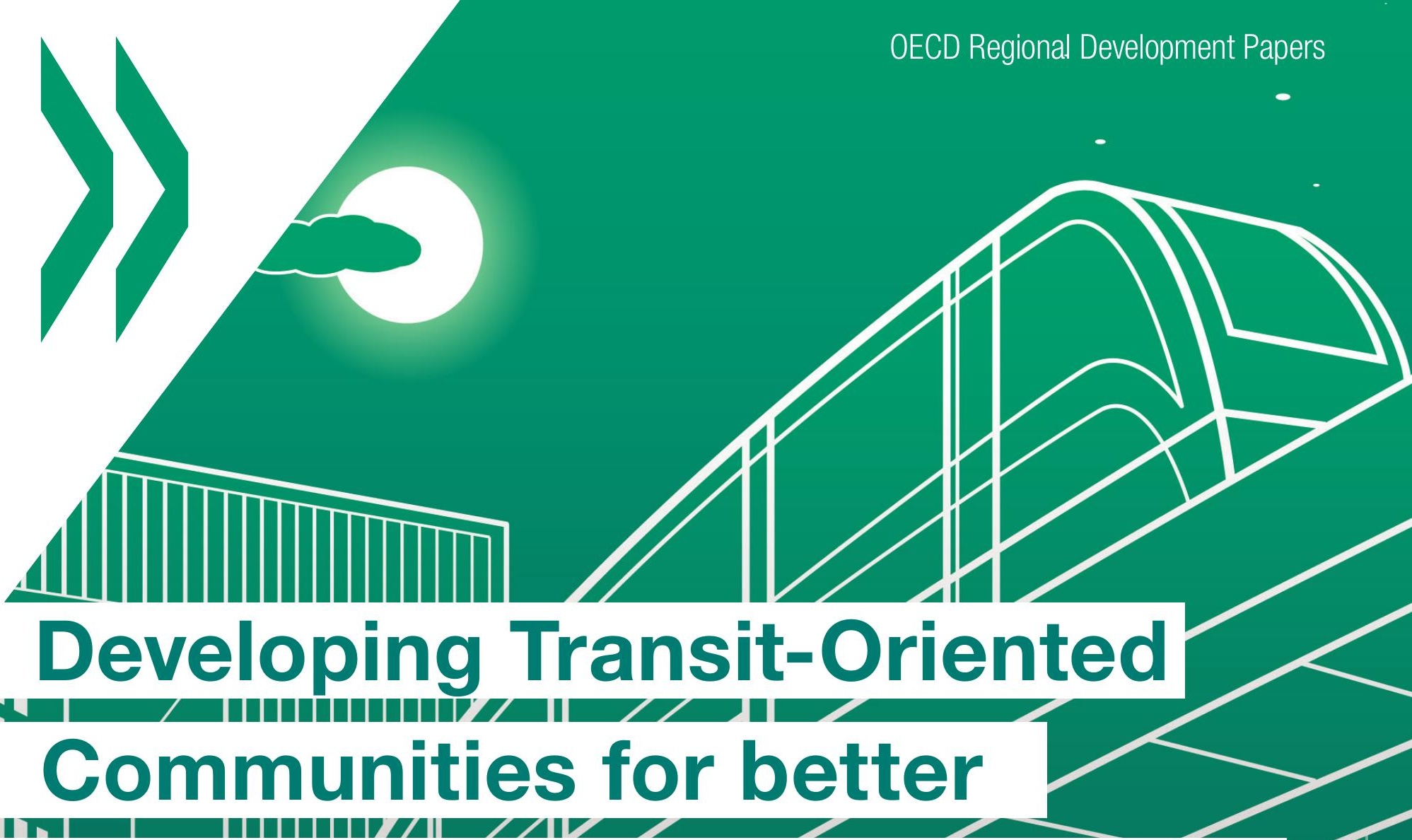

\title{
Accessibility and Affordability
}

W

Hif
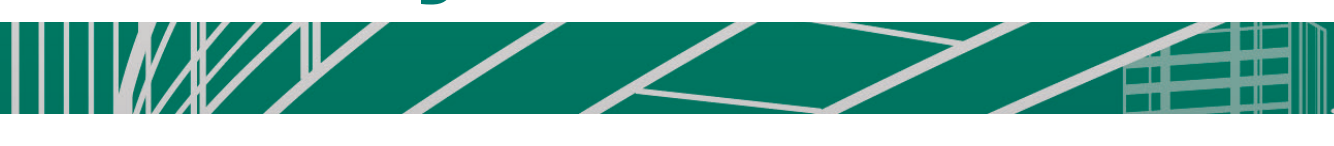

HThe case of the Metro Vancouver Region int II

\begin{tabular}{l}
1 \\
7 \\
\hline
\end{tabular}
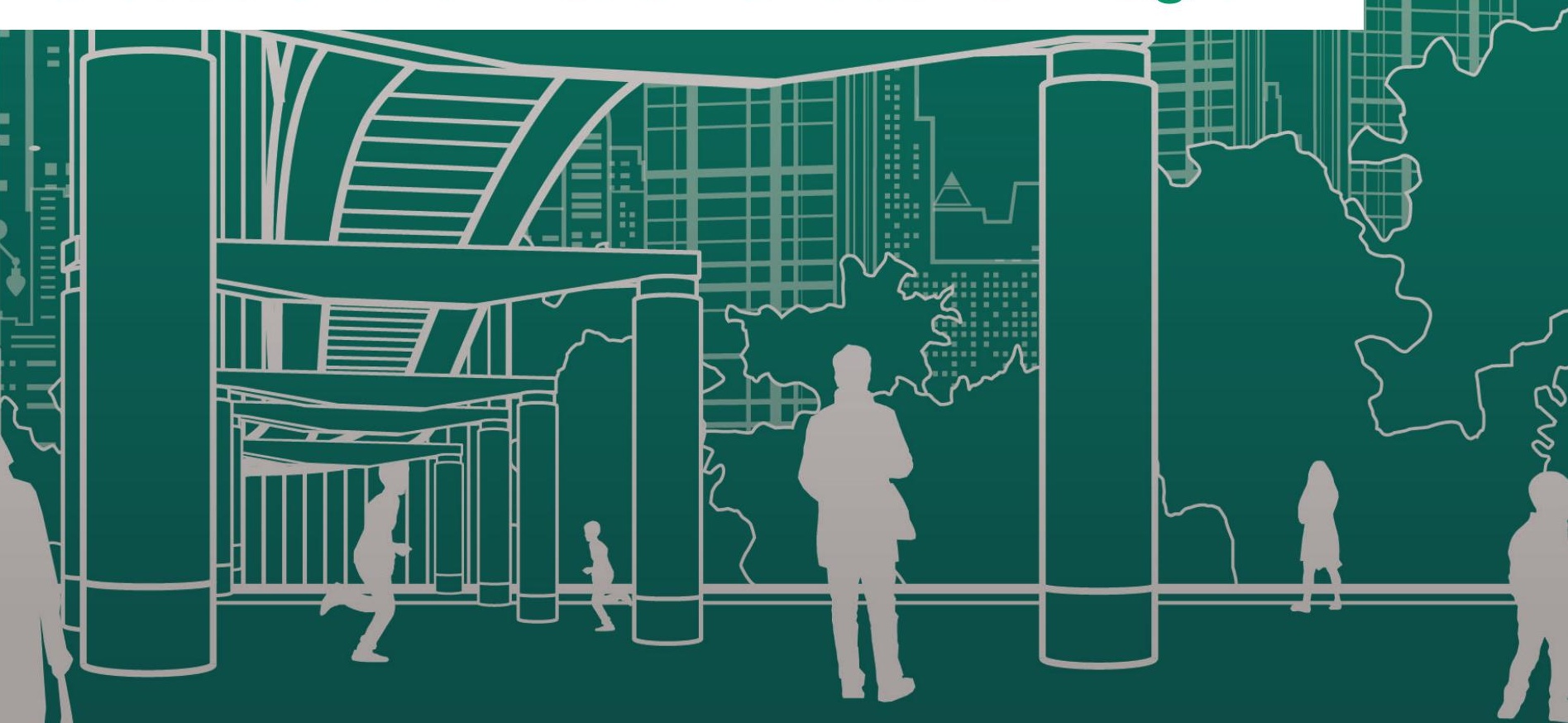

\section{(-) J)ECD}


OECD Regional Development Papers

\title{
Developing Transit-Oriented Communities for better Accessibility and Affordability
}

\section{The case of the Metro Vancouver Region}

By: Oscar Huerta Melchor and Alexander C. Lembcke

\begin{abstract}
The development of transit-oriented communities (TOC) is a central element in the promotion of accessibility in the Metro Vancouver Region (MVR). The entity is building on its wealth of experience in public transport development in the region, which has contributed to its high levels of wellbeing and economic progress. TOC aims to incentivise people to drive less and walk, cycle and take transit more. A solid culture of community engagement, the existence of a coordinating body for transport planning, and the links between transport and land-use policy are the main assets MVR has to enhance accessibility. However, tackling the affordable housing deficit around transport hubs remains a challenge for local authorities. The purpose of this paper is to draw lessons from the MVR's experience in transit-oriented initiatives to contribute to the development of compact, connected and green urban centres.
\end{abstract}

JEL codes: R0, R40, R140, R420, R21, R28, R50, R58, H70

Keywords: Urban accessibility, transport, mobility, transport planning

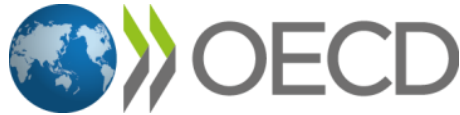




\section{ABOUT THE OECD}

The OECD is a multi-disciplinary inter-governmental organisation of 37 member countries, which engages in its work an increasing number of non-members from all regions of the world. The Organisation's core mission today is to help governments work together towards a stronger, cleaner, fairer global economy. Through its network of 250 specialised committees and working groups, the OECD provides a setting where governments compare policy experiences, seek answers to common problems, identify good practices, and coordinate domestic and international policies. More information available: www.oecd.org.

\section{ABOUT OECD REGIONAL DEVELOPMENT PAPERS}

Papers from the Centre for Entrepreneurship, SMEs, Regions and Cities of the OECD cover a full range of topics including regional statistics and analysis, urban governance and economics, rural governance and economics, and multi-level governance. Depending on the programme of work, the papers can cover specific topics such as regional innovation and networks, sustainable development, the determinants of regional growth or fiscal consolidation at the subnational level. OECD Regional Development Papers are published on http://www.oecd.org/cfe/regional-policy.

This paper is published under the responsibility of the Working Party on Urban Policy (WPURB) of the OECD Regional Development Policy Committee (RDPC) on 7 December 2020 under the cote [CFE/RDPC/URB(2020)24]. The opinions expressed and the arguments employed herein do not necessarily reflect the official views of OECD member countries.

This paper is authorised for publication by Lamia Kamal-Chaoui, Director, Centre for Entrepreneurship, SMEs, Regions and Cities, OECD.

This document, as well as any statistical data and map included herein, are without prejudice to the status of or sovereignty over any territory, to the delimitation of international frontiers and boundaries and to the name of any territory, city or area.

This publication was produced with the financial support of the European Union. Its contents are the sole responsibility of Oscar Huerta Melchor and Alexander C. Lembcke and do not necessarily reflect the views of the European Union.

\section{(C) OECD 2020}

You can copy, download or print OECD content for your own use, and you can include excerpts from OECD publications, databases and multimedia products in your own documents, presentations, blogs, websites and teaching materials, provided that suitable acknowledgement of OECD as source and copyright owner is given. All requests for public or commercial use and translation rights should be submitted to rights@oecd.org. 


\section{Acknowledgements}

This policy paper was produced by the OECD Centre for Entrepreneurship, SMEs, Regions and Cities (CFE) led by Lamia Kamal-Chaoui, Director. It is part of the Programme of Work of the OECD's Regional Development Policy Committee (RDPC) and its Working Party on Urban Policy.

The policy paper was prepared as part of a wider project on Rethinking urban and regional transport needs: improving access, safety and well-being through transport investment and policies, jointly implemented by the CFE and the OECD's International Transport Forum (ITF). The financial contributions from the Directorate-General for Regional and Urban Policy of the European Commission and the support and feedback received at various stages of the project by Lewis Dijkstra are gratefully acknowledged.

The OECD Secretariat would like to thank the numerous local officials and experts that met with the OECD team and provided valuable insights in Vancouver. In particular, the OECD Secretariat is grateful to Andrew Devlin, Andrew McCurran and Kyle Rosenke from TransLink as well as Heather McNell and James Stiver from Metro Vancouver for their kind assistance in organising the study mission and providing valuable information for the case study.

The policy paper was drafted by Oscar Huerta Melchor, Policy Analyst in the Cities, Urban Policies and Sustainable Development Division, CFE, with the support and inputs from Alexander C. Lembcke, Policy Analyst in the Economic Analysis, Statistics and Multi-level Governance section, CFE, under the supervision of Rudiger Ahrend, Head of the Economic Analysis, Statistics and Multi-level Governance section in CFE. The working paper was reviewed and commented by Stephen Perkins and his team at the OECD International Transport Forum. The policy paper benefitted from comments from Soo-Jin Kim, Deputy Head of the Cities, Urban Policies and Sustainable Development Division, CFE.

This policy paper was submitted to delegates for approval by written procedure by 7 December 2020 under the cote [CFE/RDPC/URB(2020)24]. Andrew Brenner edited the final version, and Pilar Philip prepared the manuscript for publication. 


\section{Table of contents}

Acknowledgements 3

Executive Summary $\quad 6$

1 Introduction $\quad 9$

2 An overview of the Metro Vancouver Region 11

MVR strong economic foundations 11

MVR long-term urban challenges 11

Investing in transport to maintain high-living standards 12

3 The planning framework 14

MVR long term development vision 14

Developing 'complete communities' through a transit-oriented approach 17

The best transport plan is a good land use plan 18

Planning at local level - a framework for managing change $\quad 19$

4 The regional transport strategy 22

Investing in transport and residents' well-being 22

Sustainability, low-cost and distance reduction at the core of the strategy

Rethinking transport to foster accessibility $\quad 27$

5 Transit-oriented affordable housing 31

A new way of looking at affordability: housing + transport costs 31

Tackling the affordable housing challenge via transport investment 33

6 The governance framework for transport accessibility 34

Transport provision requires multi-level governance 34

Creating partnerships to make integrated policy transport solutions 36

Funding for transport via partnerships 36

Strong community engagement underpins transport projects 38 
7 Reinforcing MVR's accessibility strategy 39

In Conclusion - what lessons can be learned from MVR on fostering accessibility? 43

References $\quad 46$

\section{FIGURES}

Figure 1. Vancouver's regional transportation vision in context 14

Figure 2. Metro Vancouver Frequent Transit Network $\quad 23$

Figure 3. Key regional transit connections in MVR 23

Figure 4. Usual mode of travel to commute in the city of Vancouver, 2017

Figure 5. Transport hierarchy $\quad 27$

Figure 6. Housing and transportation cost burden, 2015

Figure 7. Proposed actions to support the MVR accessibility strategy 40

\section{TABLES}

Table 1. New Bus and HandyDART investments in Phase Two of the 10-Year Plan 13

Table 2. A comparison of TransLink's and Metro Vancouver's regional targets 18

Table 3. Share of commuters working outside home subregion, $2011 \quad 24$

Table 4. Strategic transport investment - key actions 28

Table 5. 10-Year Vision: progress on delivering Phase One 29

Table 6. Strategic actions for the more efficient and user-focused public transport system 30

Table 7. Strategies to build strong partnerships, ensure funding, and perform assessments 37

Table 8. Analysing the Metro Vancouver Region's accessibility experience 39 


\section{Executive Summary}

The Metro Vancouver Region (MVR) in British Columbia, Canada, is the third-largest metro region in the country. It produces over 60\% of the province's real GDP. Between 2013 and 2017, the MVR had an average annual real GDP growth of $3.9 \%$, while the national average was $2.1 \%$. However, despite having high levels of well-being, the region faces important challenges: underinvestment in public transit and road infrastructure; poor housing affordability; land scarcity for port expansion; low labour productivity levels; and stalled educational attainment rates. Transportation-related issues have been a priority for policymakers in the region for the last two decades as the conditions of streets and roads, traffic congestion, long commute times, the quality and level of public transit, road safety and parking deteriorate. The lack of affordable housing is a growing concern for citizens. For low- and medium-income households accessing affordable housing close to transport hubs is very complicated due to high housing prices. There is an estimated yearly shortfall of 2400 affordable housing units for lower income households in the MVR. High housing costs and long commuting distances are preventing businesses from attracting and retaining highly qualified personnel.

To rise to the mobility and accessibility challenges, the MVR has had a consistent long-term development vision supported by transport investments. The Regional Growth Strategy and the Regional Transportation Strategy, the two main strategic planning documents, underpin the 10-year investment plans, as well as the municipal transportation and economic development plans. The Regional Growth Strategy contains the region's goals, actions and strategies on land use policies to guide development -mostly around Frequent Transit Development Areas (FTDA) - and to support the efficient provision of transport, regional infrastructure and community services, as well as to protect air quality and reduce greenhouse gas emissions. COVID-19 has underlined the importance of building compact, connected and clean cities as it makes it easier for residents to access health and social services, create support networks and use the city's social infrastructure (i.e. community institutions). OECD research has shown that density alone is not what make cities vulnerable to COVID-19, but the structural economic and social conditions of the cities determine their ability to implement effective policy responses. Thus, MVR's promotion of transit-oriented communities (TOC) is likely to have a positive impact on the recovery efforts from the COVID-19 pandemic and make the region better prepared for future similar events.

The MVR aims to build walkable, mixed-use, transit-oriented communities where people can work, access services, live and enjoy social, cultural, educational and recreational pursuits. Providing diverse and affordable housing choices to meet current and future demand is a key objective of this strategy. For regional planning authorities, this is an effective way of concentrating growth on brownfield sites while generating and attracting transit ridership. This will enable people to drive less and walk, cycle and take transit more. For this purpose, authorities have been coordinating land use and transport strategies as the location of jobs and housing fundamentally determines where and how long people, goods and services need to travel.

Investing in transport infrastructure has been central to achieving high levels of well-being in the region. The transport vision for the region is to meet all the transport needs in a way that enhances the health of the people, communities, economy and environment to maintain the high living standards that characterise 
the region. MVR has an integrated transport system that offers different options for moving around the metropolitan area: an extensive bus network, the SkyTrain system, and SeaBus services. Authorities estimate that approximately 6.06 million daily trips are made using public transport on a typical fall weekday in the region. Moreover, the MVR is working to reduce congestion and improve public and environmental health at the lowest net cost by investing in walking and cycling. To unlock cycling's potential, trafficprotected bikeways are being built that will improve safety and comfort. However, regional planning authorities have noted that infrastructure alone cannot resolve transportation problems, especially if new infrastructure results in people traveling farther or more frequently.

Regional transport requires coordinated and collaborative efforts from many stakeholders including TransLink (the regional transport planning and service provider authority), Metro Vancouver (the regional planning authority), the different municipalities, upper levels of governments, the private sector, community organisations, and residents. These actors form partnerships to align land-use and transport planning to ensure that homes, work places and industrial areas are arranged in such a way that people and goods do not have to travel long distances. Local authorities work in close cooperation with Metro Vancouver and TransLink to achieve coherence in investment decisions but this is not always easy. Metro Vancouver has to make policy for the local level at the regional level, but municipalities are in charge of implementation based on their own plans and priorities.

A key element to realise the accessibility vision in the MVR is to ensure stable, sufficient and appropriate funding that is both affordable and equitable for the region's inhabitants. TransLink has taxation authority and since 2008 receives funds from the carbon tax. It also receives a proportion of the fuel tax and property tax for funding transport investment plans. Other sources of revenues include smaller fees. The federal government contributes $40 \%$ of TransLink's income. Finding the right mix of funding sources in the short and long term requires the creation of partnerships, which should include contributions from the federal, provincial and local level governments.

The MVR's strategic goals are based on extensive consultation and discussion with residents and a wide range of stakeholders. Community engagement (public participation or public involvement) is considered in the region a fundamental civic goal in the aim of creating an engaged city to address issues of shared importance and solve them, while creating positive social change. This has allowed authorities to generate support for their initiatives and base their proposals on real needs.

To build transport-oriented communities with better access to jobs, goods and services, and contribute to the recovery efforts from COVID-19 authorities need to manage the trade-offs among people's individual needs and abilities, land use decisions, transport options, and a transport network that meets users' varying needs. This is not an easy balance to strike. Despite its relative success and progress in planning and transforming MVR into transport-oriented communities, further progress will require action in at least four areas:

- Ensuring affordable housing for low- and middle-income households in areas with access to a range of services and amenities including public transport services. Proximity to transit stations tends to raise the cost of housing, making it hard for low- and middle-income households to find accommodation in central areas. Authorities could explore the feasibility of introducing housing subsidies for low-income households. In allocating the subsidy, priority should be given to transitoriented developments that include an affordable component and have a plan to deal with undesired spillover effects. It is preferable to require a thorough assessment of the spillover effects of any transport expansion (e.g., rising housing prices) well before the project gets underway. This could come in the form of a plan that ensures housing remains affordable.

- Adopting a smart city and smart mobility framework that prepares and guides the region for the adoption of digital technologies to boost well-being and deliver more efficient and sustainable transport options. For that, Metro Vancouver and TransLink could revise and adapt the regulatory framework to enable the use of digital technology for mobility services. It is important that regulation 
be flexible in order to account for many unknowns around the uptake and impact of technologies and services. MVR would need to prepare its legislation, planning and infrastructure for moving to electric and automated vehicles. TransLink needs to explore the potential policy and investment priorities to prepare for these emerging trends as part of the update to the Regional Transportation Strategy.

- Making the model for funding transport infrastructure projects more sustainable and less dependent on a single tax. The financing of transport projects is heavily reliant on the fuel tax despite the formation of partnerships. TransLink could explore other sources of revenue, particularly those that affect behavioural change. For instance, land value capture schemes, development cost charges or benefiting from capture taxes could be considered but they should be in line with the policy goals of the provincial government.

- Improving the infrastructure for walking and cycling, in particular building pavements (sidewalks) and bike lanes in some municipalities would be a priority. TransLink and local authorities are already working to solve this problem by financing the construction of pavements which are seen as a means of transportation to encourage active mobility. The programmes to complete the bicycle network in some municipalities need to continue.

What lessons does MVR offer about accessibility?

- To maintain and increase the levels of well-being and economic growth, investment in public transport is essential.

- Pursuing accessibility is a long-term continuous investment process.

- Local development planning, land use planning, and transport policy need to work in a coordinated fashion based on a regional/metropolitan approach.

- Building transport-oriented communities requires giving pedestrians the highest priority.

- Housing affordability and public transport need to be considered in tandem to improve quality of life, competitiveness and productivity in cities.

- The creation of a regional body for the coordination of the transport strategy and the close cooperation with the regional planning authority to enable coherence in decision-making.

- The creation of partnerships among different actors may facilitate policy-making, and financing for implementation.

- The success of transport projects and land use plans require a high level of civic engagement. 


\section{Introduction}

Remaining transit-oriented is one of the main challenges for transport and urban policy in the Metro Vancouver Region (MVR), in British Columbia, Canada. The COVID-19 pandemic is a health crisis that is changing people live in cities and the conception of what a city should be. The risk for metropolitan areas, like the Metro Vancouver Region, is that health concerns could translate into a setback on progress made to build sustainable cities. MVR has been an example of the promotion of public transport in North America. However, the current social distancing measures linked to the public health crisis may have a negative impact on urban planning and public transport policy.

Like in many cities around the world, public transit ridership has fallen due to lockdowns to stop the spread of the COVID-19 virus. Daily passengers numbers plummeted as almost $70 \%$ of residents who normally take public transport stopped doing so during the outbreak. ${ }^{1}$ This has also represented a fall in revenue. Ridership, which is the main source of income of TransLink (the metropolitan transport authority), has fallen $80 \%$. Since driving is also down $60 \%$, the revenue from the fuel tax has also fallen significantly. Although TransLink has financial reserves, these will not last long. Financial assistance from regional and national governments will likely be necessary to maintain the service levels. TransLink considers that a rescue package of CAD 250 million (USD 187 million approximately) would enable it to maintain the service levels and prepare the transport network to resume normal service when the health emergency abates.

People's fear of contagion of COVID-19 is affecting their mobility habits. An online survey conducted on behalf of TransLink in June 2020 showed that over one-third of the population expected to increase their private vehicle use and another third expected to decrease their use of public transport. ${ }^{2}$ Active transportation trips (cycling and walking) will likely increase, particularly in the most compact and central areas of MVR such as the City of Vancouver. However, $65 \%$ of respondents indicated that funding for public transport investment will most likely influence how they move about in the MVR, followed by public health concerns and land-use policies. The key question for local authorities is how to obtain the necessary resources for public transport and, in a time when public transport usage declines due to the impact of COVID-19, how to justify investments in new public transport infrastructure.

According to Statistics Canada, $40 \%$ of the jobs in the country can be done from home. ${ }^{3}$ Although authorities expect that telework will not replace but complement normal office work, it is probable that it will have an impact on the demand for public transport services. Fewer workers would be expected to commute and thus demand for public transport service may see a decrease. Moreover, the current initiatives on smart mobility, which refer to the application of (mainly digital) technologies to improve mobility outcomes, will also be instrumental on how people travel (ITF/OECD, 2020[1]).

Becoming more car-oriented is one possibility in the post-COVID-19 period. For some people, their car is a way to ensure safety, comfort and confidence. But this would be to the detriment of the looming environmental crisis caused by climate change. How can urban areas like MVR react to the effects of the COVID-19 pandemic without compromising their longer-term response to climate change and environmental protection? This is a question that requires a wide debate and analysis. Three issues may be raised at this point. First, the viability of the economic recovery strategy and environmental protection is linked to the promotion of public transit - as not all jobs can be done remotely. Second, many people may be willing to avoid commuting to work or access services, so they would prefer working close to where they live. And third, the use of digital technologies for communication and smart mobility projects may 
decrease the environmental burden linked to congestion and improve equitable accessibility outcomes but decrease the demand for public transport.

The Canadian stimulus package to support the economy during the current COVID-19 crisis has been successful in attaching green conditions to the support provided to different sectors of the economy including transport (Vivideconomics, 2020[2]). MVR has thus the opportunity to transform the COVID-19 crisis into an opportunity to promote policies that are environmentally friendly and improve the quality of urbanisation such as urban accessibility. Thus, for MVR the promotion of transit-oriented communities (TOCs) is a valuable tool to respond to COVID-19, facilitate access to jobs and services, and contribute to the country's effort in climate change adaptation.

Enhancing urban accessibility, which refers to how easily residents can reach local services and jobs either on foot, bicycle or public transport (OECD, 2012[3]), is at the core of TOCs. Accessibility is attuned with compact cities as it requires proximity and connectivity. Indeed, compact cities characterised by dense and proximate development patterns, built-up areas linked by public transport systems, and accessibility to local services and jobs have long been presented as a way to achieve environmental, economic and social benefits (OECD, 2012[3]). If planned properly, urban accessibility would provide more flexible and varied commuting options to residents, favour a more compact urban development that brings services closer to citizens' neighbourhoods, and reduce environmental impact. According to OECD research, COVID-19 has allowed cities to shift from focusing on mobility to promoting accessibility by revisiting public space, urban design and planning (OECD, 2020[4]). This requires building compact, connected, and clean cities. COVID19 has highlighted that in dense compact environments with high levels of accessibility it is possible to provide quicker access to health and social services, create support networks to combat social isolation and make better use of social infrastructure to alleviate the consequences of the pandemic. Research has shown that it is not density alone that makes cities more vulnerable to a pandemic crisis such as COVID19 , but the structural economic and social conditions that facilitate or hinder implementing effective policy responses (OECD, 2020[4]]).

This working paper aims to draw lessons from the experience of the Metro Vancouver Region in the building of transit-oriented communities. It will begin with an overview of the socio-economic challenges and opportunities of MVR and the role played by public transport in improving quality of life. It will then describe the planning framework and the regional transport strategy. The working paper will then explain the transit-oriented affordable housing scheme promoted in MVR as part of the development of transitoriented communities and the pursuit of equity objectives. It will then discuss the governance framework that underpins the design and implementation of the transit-oriented strategy. The working paper concludes with a series of lessons that can be drawn from this experience and some recommendations to improve the initiative. The working paper was largely prepared before the COVID-19 pandemic and the statistics and forecasts presented here do not take its impact into account. But the policy initiatives and subsequent recommendations are largely valid for the recovery efforts. 


\section{An overview of the Metro Vancouver Region}

\section{MVR strong economic foundations}

The Metro Vancouver Region (MVR) in British Columbia, Canada, is a partnership of 21 municipalities, one Electoral Area and one Treaty First Nation that collaboratively plans and delivers regional-scale services. The MVR is the third-largest metro region, in terms of population and economic activity, in Canada behind Toronto and Montreal. It occupies a land area of $2,882.68 \mathrm{~km}^{2}$. The MVR had a total population of 2.47 million inhabitants and a population density of 854.6 inhabitants per km² in $2016 .{ }^{4}$ Over the next 30 years, the population in the MVR is expected to add one million additional residents, 600000 jobs and three million more daily passenger trips on public transit. The MVR has a polycentric structure with the cities of Vancouver, Burnaby, Coquitlam, and Surrey as peaks of moderate density. This makes the region unique in that it has higher percentages of medium density not only in urban land near the centre but also on urban land areas located at some distance of the centre (OECD, 2012[3]).

MVR has enjoyed economic growth above the national average over the past 10 years. In 2017, it produced goods and services that represented $61 \%$ of British Columbia's real GDP (City Of Vancouver, 2017 ${ }_{[5]}$ ). Between 2013 and 2017 the MVR had an average annual real GDP growth of 3.9\%, while the national average was $2.1 \%$ (Black, 2018 $\left.{ }_{[6]}\right)$. This is mostly due to its ties with Asia and for the performance of its transport sector. Vancouver's geographic location on the West Coast of Canada, combined with a major truck and rail routes to a number of North American cities, makes it an excellent gateway for the movement of goods to and from the United States, the Pacific Rim, and other countries. Vancouver International Airport connects the region with Asia and meets the demand of the large Asian communities in the MVR. Due to its geographic location - isolated from much of the rest of Canada - transportation played a key role in MVR's early development as a staples-based economy (e.g. mining, logging). Approximately 50\% of MVR's economic activity is directly tied to transportation (Krawchenko, 2012[7]).

Financial services, insurance, tourism, and information technology are some of the sectors where the metro region has demonstrated its competitive advantage relative to the rest of Canada. The service sector has dominated the labour market in recent years. Moreover, professional, scientific, and technical jobs are on the rise and are slated to become MVR's third largest employer. MVR's well-educated workforce, strong economic growth, and investments in transport infrastructure are thought to be adding to the success of finance and insurance firms.

\section{MVR long-term urban challenges}

Despite its success, MVR faces challenges that hinder its socio-economic performance. According to the Conference Board of Canada $\left(2016_{[8]}\right)$, the region's longer term performance will depend on its ability to deal with seven important challenges: $I$ ) historical underinvestment in public transit and road infrastructure; ii) poor housing affordability; iii) land scarcity for port expansion; iv) low labour productivity levels; $v$ ) 
educational attainment rates; vi) high marginal effective tax rate on capital for businesses; and vii) fewer head offices than cities of comparable size. Much of the metropolitan area is characterised by low density, single family housing with regional or town centres acting as nodal and commercial focal points (Krawchenko, 2012[7]). Poor housing affordability is limiting Vancouver's attractiveness to the highly skilled workers that businesses seek. MVR's working households earn $83 \%$ of what households make in Calgary, but face $9 \%$ higher housing ownership costs, and pay nearly the same rent (Metro Vancouver, 2015, p. 8[9] . MVR's geographic position exacerbates the challenges as the region is locked between mountains, the ocean, an international border and a protected agricultural zone, leaving little room for urban expansion and to accommodate additional automobile infrastructure. According to TransLink, traffic congestion and travel time reliability are emerging challenges for the region.

\section{Investing in transport to maintain high-living standards}

In general, citizens are positive about the quality of life in MVR. In 2016, for example, the Vancouver Foundation reported that most of the people in British Columbia had a positive outlook on life and valued their quality of life. In the Metro Vancouver Region, residents value their parks and public spaces, as well as the walkability and ease of moving around (Vancouver Foundation, 2016 $\left.{ }_{[10]}\right)$. Moreover, in 2017, in the City of Coquitlam, in the MVR, $98 \%$ of citizens rate the overall quality as 'very good' (48\%) or "good" (50\%) (Ipsos, 2017[11]). The reasons for these results are the introduction of the SkyTrain Evergreen Line, and improvement in recreational facilities and in transportation. Nevertheless, in general, transportation-related issues have been at the top of the public issue agenda in the region for some years. Issues such as the conditions of streets and roads, traffic congestion, the quality and level of public transit, road safety and parking are residents' key concerns.

Long commute times may be adding to MVR's difficulties in attracting high-end talent. The failure to address the inadequate investment in transit and road infrastructure, and the housing affordability problem could keep talented people and business investment away. Infrastructure investment influences private sector competitiveness, especially if it reduces commute times for employees and for trucking goods throughout the region. The 10-year Vision for the Metro Vancouver Region, as formulated by the Mayors' Council, seems to be a step in the right direction. For instance, the provincial government and the regional transportation authority TransLink recently spent CAD 1.43 billion (USD 971 million approximately) to extend the SkyTrain service to the region's Tri-Cities area (The Conference Board of Canada, 2016, p. $74[8])$. Phase Two of the 10-Year Vision investment plan includes upgrades to the Expo and Millennium lines of the rail rapid transit system at an estimated cost of CAD 1.30 billion (TransLink, 2018[12]). Actions include replacing the ageing fleet and expanding capacity, upgrades to operations and maintenance centres, station upgrades to increase passenger capacity accessibility and improve neighbourhood integration, and more frequent service during peak periods. For the MVR, the recurring challenge is to ensure industry and commerce have an adequate supply of space throughout the region. That space, of course, must be located in areas that fulfil their needs and support an efficient transport system on which the economy can depend. 
Table 1. New Bus and HandyDART investments in Phase Two of the 10-Year Plan

\section{Highlights}

\begin{tabular}{|c|c|c|}
\hline & Investments already funded in Phase One & New Investments funded in Phase Two \\
\hline \multirow[t]{4}{*}{ Bus } & $\begin{array}{l}\text { Increase bus service by } 10 \% \text { across the region from } 2017 \text { - } \\
2019 \text {. }\end{array}$ & $\begin{array}{l}\text { Increase bus service by } 8 \% \text { across the region from } 2020 \text { - } \\
2021 \text { (ex. improve service on at least } 75 \text { different bus } \\
\text { routes). }\end{array}$ \\
\hline & $\begin{array}{l}171 \text { new buses for Phase One bus service improvements, in } \\
\text { addition to new buses replacing ageing fleet. }\end{array}$ & $\begin{array}{l}151 \text { new buses for Phase Two bus service improvements, } \\
\text { in addition to new buses to replace ageing fleet. }\end{array}$ \\
\hline & $\begin{array}{l}\text { Upgrades to bus exchanges, such as operational } \\
\text { improvements, customer amenities, safety and accessibility } \\
\text { enhancements. }\end{array}$ & $\begin{array}{l}\text { Provide CAD } 87 \text { million in new funding for transit priority } \\
\text { projects and enhanced passenger amenities on new B- } \\
\text { line corridors. }\end{array}$ \\
\hline & $\begin{array}{l}\text { Provide CAD } 57 \text { million in new funding for transit priority } \\
\text { projects and enhanced passenger amenities. }\end{array}$ & $\begin{array}{l}\text { Provide CAD } 12 \text { million in new funding for regional transit, } \\
\text { especially bus services across the region to improve bus } \\
\text { speed and reliability. }\end{array}$ \\
\hline Seabus & $\begin{array}{l}\text { SeaBus sailing every ten minutes during peak periods and } \\
\text { every } 15 \text { minutes at other times } \\
\text { New SeaBus vessel. }\end{array}$ & SeaBus sailing to meet the last Canada Line train. \\
\hline HandyDART & $\begin{array}{l}\text { Increase HandyDART service by 15\% from } 2017 \text { to } 2019 \text {. } \\
23 \text { new buses for Phase One HandyDART service } \\
\text { improvements, in addition to new buses to replace ageing } \\
\text { fleet. }\end{array}$ & $\begin{array}{l}\text { Increase HandyDART service by } 7 \% \text { from } 2020 \text { to } 2021 \text {. } \\
20 \text { new buses for Phase Two HandyDART service } \\
\text { improvements, in addition to new buses to replace ageing } \\
\text { fleet. }\end{array}$ \\
\hline
\end{tabular}

Note: HandyDART is a door-to-door, shared ride service for passengers with physical or cognitive disabilities who are unable to use conventional public transit without assistance.

Source: (TransLink, 2018, p. 11 [13]). 


\section{The planning framework}

\section{MVR long term development vision}

One of the main assets of the Metro Vancouver Region (MVR) is its consistent vision for regional growth management, supported by an effective transport system. Given the region's limited land base and its rapidly growing population, local and regional authorities have constantly focused growth and development in series of compact centres that would be easy to get around and would allow for the preservation of parks, natural spaces and agricultural lands.

In the MVR, coordinated regional planning dates back to the 1970s with the publication of the proposals to manage the growth of Greater Vancouver (Metro Vancouver, 1976[14]]). But it was not until 2002 that MVR formally put sustainability at the core of the operational and planning aspects of its comprehensive regional planning framework. There are at least two strategic planning documents at regional level that provide direction and vision for socio-economic development and transport vision: the Regional Growth Strategy and the Regional Transportation Strategy, which work in coordination. Together, these two documents underpin the definition of the 10-year investment plans, as well as the municipal transportation and economic development plans (Figure 1).

Figure 1. Vancouver's regional transportation vision in context

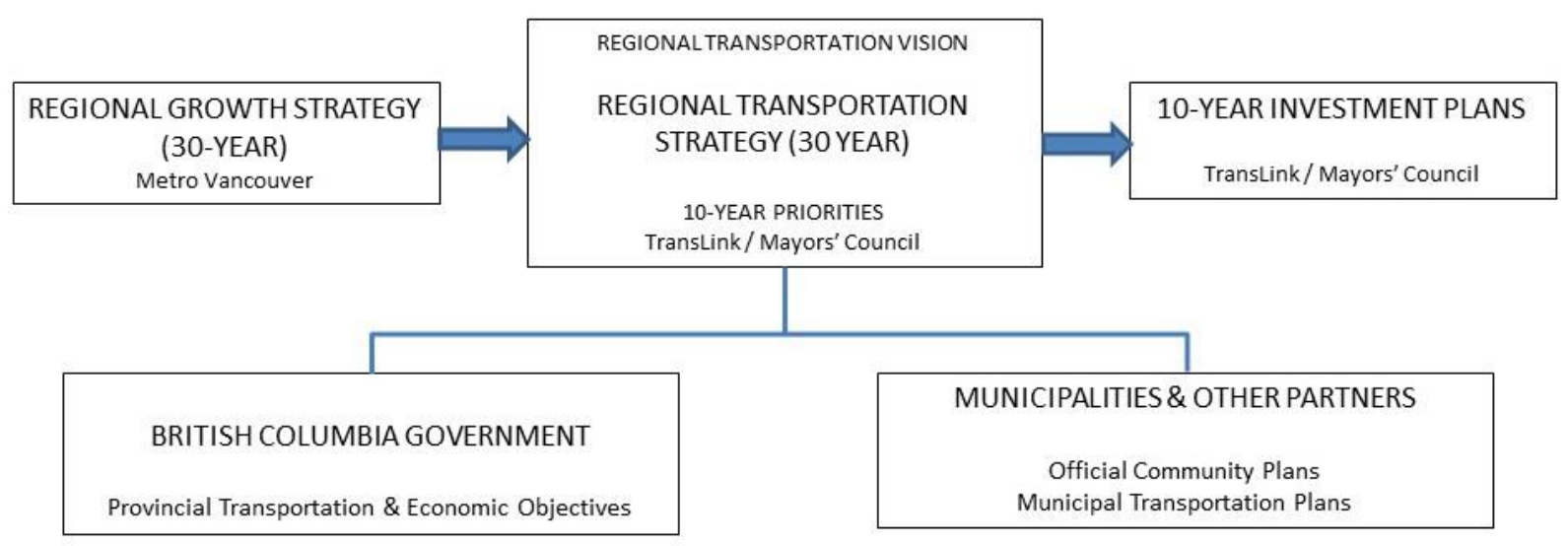

Source: (Mayors'Council on Regional Transportation, 2017, p. $\left.3_{[15]}\right)$.

Metro Vancouver 2040: Shaping Our Future is the Regional Growth Strategy (RGS), a high-level land use plan, which contains the region's goals, actions and strategies. It focuses on land use policies to guide development - especially Frequent Transit Development Areas (FTDA) - and to support the efficient provision of transport, regional infrastructure and community services, as well as to protect air quality and reduce greenhouse gas emissions (Mayors'Council on Regional Transportation, 2017, p. 2[15]). The RGS is one plan among a suite of interconnected management plans developed around Metro Vancouver's Sustainability Framework, for instance Metro Vancouver's Integrated Air Quality and Greenhouse Gas Management Plan; TransLink's Regional Transportation Strategy; and the Regional Transportation 
Investment Vision by the Mayors' Council on Regional Transportation. The RGS and the Regional Transportation Strategy are mutually reinforcing. For instance, all five goals in the RGS (Box 1) are relevant to the planning and delivery of a sustainable transport system (TransLink, 2012[16]).

In the context of MVR, the RGS is a tool to face the challenge of accommodating strong population growth (35 000 new residents are expected each year) but still contributing to advance liveability and sustainability. MVR's strategy is to focus growth in urban centres and FTDAs. The RGS considers that growth without urban sprawl implies greater density but if carefully structured this can reduce congestion, improve the economics of transport infrastructure and public services. It can also increase the viability of retail and service centres, and foster accessibility. The RGS also provides strategic actions for local and regional planning, which ensures that people have access to the key elements of a healthy social community: shops, personal services, community activities, recreation, employment, culture, entertainment and a safe and attractive public environment.

\section{Box 1. Metro Vancouver 2040 - regional goals}

The Metro Vancouver 2040 is the regional growth strategy (RGS) adopted in 2011 and was developed around Metro Vancouver's Sustainability Framework. It is centred on five regional goals that reflect the vision for the region development. Each goal has related strategies and policies that explain how they can be achieved and the actions that the regional authority - Metro Vancouver - and the member municipalities should take.

Goal 1: Create a compact urban area - The Metro 2040 Vision is that population is concentrated in compact communities with access to a range of housing choices, employment, amenities and services. Compact, transit-oriented development patterns help to reduce greenhouse gas emissions and population, and support both the efficient use of land and an efficient transportation network.

Goal 2: Support a sustainable economy - The land base and transportation systems required to nurture a strong regional economy are maintained and the labour force is supported. Industrial and agricultural land is protected and the business sectors dependent on this land thrive, while commerce flourishes in urban centres throughout the region.

Goal 3: Protect the environment and respond to climate change impacts - A connected network of habitats is maintained for a wide variety of wildlife and plant species. Protected natural areas provide residents and visitors with diverse recreational opportunities. Metro Vancouver and member municipalities meet their greenhouse gas emission targets, and prepare for, and mitigate risks from, climate change and natural hazards.

Goal 4: Develop complete communities - Metro Vancouver is a region of communities with a diverse range of housing choices suitable for residents at all stages of their lives. The distribution of employment and access to services and amenities builds complete communities throughout the region. Complete communities are designed to support walking, cycling and transit, and to foster healthy lifestyles.

Goal 5: Support sustainable transportation choices - Metro Vancouver is compact, transit-oriented, and urban, which is conducive to a range of sustainable transportation choices. This pattern of development i) expands opportunities for multiple-occupancy vehicles, transit, cycling and walking; ii) encourages active lifestyles; iii) improves air quality; and, iv) reduces energy use, greenhouse gas emissions and household expenditure on transportation. The region's road, transit, rail and waterway networks play a vital role in serving and shaping regional development by providing linkages among communities and reliable routes for the movement of goods.

Source: Metro Vancouver Regional District (2011[13]); and Metro Vancouver website www.metrovancouver.org/services/regionalplanning/metro-vancouver-2040/goals/Pages/default.aspx. 
The Regional Transportation Strategy (RTS) outlines TransLink's 30-year long-term vision for transport in support of the RGS and provincial and regional economic and environmental objectives (Box 2). The key point in the RTS is that it provides a blueprint for city building as designing communities and transportation systems should be done in tandem. The RTS is the strategic planning document that outlines regional goals, objectives and policy direction for transportation. The current '10-Year Vision' document developed by the Mayors' Council delineates the CAD 7 billion (USD 5.2 billion approximately) total investment priorities required to advance the goals of the current RTS, which include major capital investment and increases in bus services. For that, the design of community and transport decisions aim to make it possible for half of all trips to be made by walking, cycling, and transit. In addition, the distances people drive should be reduced by one-third. TransLink (the regional transport authority) is responsible for implementing the majority of the policies and actions outlined in Regional Transportation Strategy. It gets support from the 21 different local authorities in the region. Local authorities make their own decisions about local transportation decisions. The challenge is that this may lead to inconsistencies between regional plans and local implementation strategies.

\section{Box 2. Strategic framework: vision and goals on transport for the Metro Vancouver region}

Vision: "As a region, we maintain our global position as one of the best places in the world to live because we meet our transportation needs in a way that simultaneously enhances the health of our people and communities, economy, and environment."

Goals: Transportation decisions should:

- Provide sustainable transportation choices and support a compact urban area;

- Foster safe, healthy, and complete communities;

- Enable a sustainable economy;

- Protect the environment.

Source: (TransLink, 2013, p. 14[17])

Each level of government has its own role in meeting the objectives of the regional growth, development and transportation vision. The RGS and TransLink's long-term transportation strategy comprise the region's long-term vision for the land use and transportation system. The province prepares provincial highway and transit plans which inform regional transportation plans. The federal government and the province play significant roles in funding regional transit and goods movement infrastructure.

In 2014, the Mayors' Council developed the 10-Year Vision for Metro Vancouver Transit and Transportation. It is a plan that reflects an agreement by all local governments across the region, and is supported by a coalition of community, environmental and business stakeholders. It is a region-wide, integrated plan (transport, light rail, bus, roads and bridges), that supports the 30-Year Regional Transportation Strategy and Regional Growth Strategy. The 10-Year Vision is implemented in three phases, each timed to deliver new projects and services. Phase One was launched in 2017 and includes a wide range of transit service improvements. In each phase, investments from the federal and provincial governments are expected to be matched with regional revenues to ensure the 10-Year Vision is funded in a fair and balanced way. Some of the service improvements considered in Phase One are: a 10\% increase in bus service; a 15\% increase in HandyDART service; a $20 \%$ increase in rail service; new funding for improvements to the Major Road Network, expansion and improvements to the cycling and walking networks; among others. ${ }^{5}$ 


\section{Developing 'complete communities' through a transit-oriented approach}

The development of 'complete communities' is one of the strategic goals of both the RGS and RTS. Complete communities are understood to be walkable, mixed use, transit-oriented communities where people can work, access services, live and enjoy social, cultural, educational and recreational pursuits. Providing diverse and affordable housing choices to meet current and future demand is central to the idea of complete communities. Access to a wide range of services and amenities close to home, and a strong sense of regional and community identity and connection are also considered important to promote health and well-being. An important strategy in the setting of complete communities is to design neighbourhoods within urban areas, urban centres, and local centres that are accessible for people of all ages and physical ability, promote transit, cycling and walking. However, the implementation of the initiative is perhaps its weakest point as local councils must implement it individually, but they still need support provided by Metro Vancouver (the regional planning authority).

In the MVR, residents have greater choice in how they get around. More than $90 \%$ of the places where people live and work can be reached by public transport at higher levels than cities of comparable size in North America (TransLink, 2013[17]). The MVR, for example, has a similar population size than neighbouring Portland (US) (around 2 million at the metropolitan level) but the journey-to work distance is shorter in the MVR (7.4 kilometres) than in Portland (13.84 kilometres) (OECD, 2012[3]). Moreover, compared to other metropolitan areas in Canada, the MVR has managed to reduce the journey-to-work distances for the working population even as employment and population grew (OECD, 2012[3]). Based on its compact model, it is estimated that the most affordable and efficient way of achieving liveability, environmental and economic goals is to make it possible for half of all trips in the region to be made, by 2045, on foot, by bike, or public transit. These are the lowest-cost and lowest-impact forms of transport (TransLink, 2013, p. 5[17]). This would contribute to accommodating population growth and maintaining or improving travel time reliability for commuters and for goods movement on the regional road-system, even in the face of physical and economic constraints. However, transport authorities acknowledge that in order to achieve this goal, the uniqueness of each part of the region must be taken into account as they support different levels of walking, cycling and transit based on their context, location, and stage of development.

In MVR, sustainable urban development is being shaped around the 'transit-oriented development' (TOD) approach. TOD is considered an effective way of concentrating growth in brownfield sites, while generating and attracting transit ridership to shift mode shares. In MVR, and particularly in the City of Vancouver, the SkyTrain rapid transit system has shaped land use planning since its inception in 1985. However, while development that capitalises on rapid transit has been relatively successful in the metro core, stations beyond the City of Vancouver have yet to pursue TOD to its full potential. This is even more important given the expected population growth in the coming decades. The RGS makes reference to the FTDA as an instrument to focus growth on urban centres. An FTDA is defined as a moderate to high-density, mixeduse residential and commercial development located around a transit station or corridor. This represents the integration of land use and transport planning which encourages a compact and pedestrian-oriented city that improves access to residential, retail, office, and community uses nearby ( $\mathrm{Ngo}, 2012[18]$ ). One of the aims is to reduce car dependency and thus maximise the functionality of the area. TODs in the city of Vancouver are typically laid out in circular or nodal arrangements, located within a radius of 400 to 800 metres, equivalent to a 5-10 minute walk from the rail-based transit stop.

However, since TODs are site-specific projects that are shaped by their close proximity to rapid transit and transport; planning authorities in MVR have also adopted the 'transit-oriented communities' (TOCs) approach. According to TransLink (2012[16]), transit-oriented communities refers to places that, by their design, allow people to drive less and walk, cycle and take transit more. It promotes higher density, mixeduse, human scale development around frequent transit stops and stations. The main difference with TOD is that TOCs are places that take access to and support for transit into account when planning and designing at a neighbourhood, corridor, municipal, or regional scale (TransLink, 2012, p. 2[16]). This is a 
planning concept that includes land use planning and community development policies. It strives to maximise access to transit as a key organising principle and acknowledge mobility as an integral part of the urban fabric. One important point is that the TOC approach goes beyond the traditional 'transit oriented development' (TOD) model which is site-specific. By connecting communities, destinations and amenities through improved access to transit, TOCs promote walkable and bikeable communities that accommodate healthier and active lifestyles, improve access to jobs and economic opportunities, and reduce greenhouse gas emissions. They also constitute, in many cases, a more cost-effective way to meet MVR's mobility needs by supporting infrastructure investment in walking, cycling, and transit rather than other measures such as widening roads or building new parking facilities (TransLink, 2012[16]). TOCs are completely in line with the development of complete communities, which is part of the regional growth strategy as it allows for a more efficient use of infrastructure and scarce land.

One potential problem is that although TOCs provide transport options for all members of the community and may reduce households' transport costs (through less driving and potentially lower automobile ownership rates) they can also create equity challenges. TODs and TOCs can disproportionately favour individuals and families that are able to pay a premium to live in valuable real estate close to rapid transit. Subsequently, lower income households have limited location choices and they often get pushed farther from better served transit areas, resulting in less equitable transit access for the less affluent (Ngo, $2012_{[18]}$. This is a critical challenge for MVR - as it is for the entire country-as problems to ensure access to affordable housing are top in the policy agenda.

\section{The best transport plan is a good land use plan}

Metro Vancouver's basic premise is that the best transport plan is a good land use plan. The reason is that achieving the goals of the RGS and the RTS requires the alignment of land use and transport strategies. The location of jobs and housing fundamentally determines where and how much people, goods and services need to travel. This coordination has characterised the MVR since the regional development plan of 1975 was implemented. It envisioned a transit-oriented region of compact urban centres linked by highquality transit. This is expected to support the development of compact areas and transit-oriented development patterns throughout the region. The idea is to reduce vehicle use, traffic congestion, energy consumption and air emissions from on-road sources while fostering transit ridership. This would provide residents with greater travel options and a cleaner environment. Therefore, regional growth and development are guided by a closely coordinated set of plans which include: Metro Vancouver's Regional Growth Strategy (RGS), TransLink's Regional Transportation Strategy (RTS), and the Official Community Plans of the local municipalities. Table 2 shows how TransLink's and Metro Vancouver's regional targets are aligned.

\section{Table 2. A comparison of TransLink's and Metro Vancouver's regional targets}

\begin{tabular}{ll}
\hline \multicolumn{1}{c}{ TransLink's targets by 2040} & \multicolumn{1}{c}{ Metro Vancouver targets by 2041} \\
\hline Most trips are by transit, walking and cycling. & $\begin{array}{l}\text { At least } 31 \% \text { of regional housing units and } 43 \% \text { of regional jobs } \\
\text { are located in urban centres. }\end{array}$ \\
$\begin{array}{l}\text { The majority of jobs and housing in the region are located along } \\
\text { the Frequent Transit Network. }\end{array}$ & $\begin{array}{l}\text { At least } 27 \% \text { of regional housing units and } 24 \% \text { of regional jobs } \\
\text { are located in Frequent Transit Development Areas (conceptual } \\
\text { targets). }\end{array}$ \\
$15 \%$ of all trips of less than 8kms are made by bicycle. & $\begin{array}{l}\text { Regional greenhouse gas emissions are reduced by at least } 33 \% \\
\text { below } 2007 \text { levels by } 2020 \text { and } 80 \% \text { below } 2007 \text { levels by } 2050 .\end{array}$ \\
\hline
\end{tabular}

Source: TransLink (2012[16]).

Land use in MVR focuses on shortening trips and promoting sustainable transport choices (cycling, walking and transit). For that, dense and mixed development as well as business activity are located near transit 
stations. The RGS provides the land use framework for planning related to utilities (water, liquid waste and solid waste), transport, housing and air quality. It emphasises the importance of coordinating land use and transportation, recognising that the location of jobs and housing determines to a large extent where and how much people, goods, and services need to travel. For instance, it requires municipalities to reduce parking requirements in new developments within Urban Centres and FTDAs; locate users that generate frequent vehicle trips in urban areas; improve municipal infrastructure to support transit, carpooling, cycling, and walking; and assess how new communities, infrastructure and transportation affect public health, including air quality and noise impacts. It also requires TransLink to prepare and implement a regional goods movement strategy. It requires provincial and federal governments to support safe and efficient goods movement by protecting rail rights-of-way and access points to navigable waterways.

To support sustainable transport choices, the RGS includes two strategies. The first one consists in coordinating land use and transport to encourage transit, multiple-occupancy vehicles, cycling and walking. For that purpose, TransLink implements its Frequent Transit Network (FTN) to reinforce the network of transit-oriented urban centres and emerging FTDAs, and shape land use in support of frequent transit. The FTN and the frequent transit development corridors are a vision for how to integrate land use, transit supportive infrastructure and frequent service (OECD, 2012[3]). The FTN comprises bus and rapid transit corridors with densities and land uses that promote maximum ridership and that provide users with reliable service at least every 15 minutes throughout the day and over the entire week. The FTN provides a network of routes around which municipalities can focus population and job growth. As of 2014 , about $54 \%$ of the region's dwellings and 65\% of jobs were within walking distance of the FTN (Metro Vancouver, 2015, p. $10_{[9]) .}$. The second strategy is to coordinate land use and transport to support the safe and efficient movement of vehicles for passengers, goods and services. TransLink's Major Road Network, provincial highways, and federal transport facilities play a critical role in shaping regional growth, moving people and goods across the region, and connecting MVR with intra-provincial, national and international destinations. According to the RGS, the active management of the existing and planned capacity of the road network could minimise the need for capital-intensive expansion in the future (Metro Vancouver Regional District, $2011_{[19]) \text {. }}$

To contribute to climate change mitigation a continued focus on urban containment and land use patterns that support sustainable transport and reduce energy use is an integral part of the RGS. For that, Metro Vancouver encourages land use and transport infrastructure that reduce energy consumption and greenhouse gas emissions, and improve air quality. The goal is to reduce greenhouse gas emissions by $33 \%$ below the 2007 levels by 2020 and $80 \%$ below the 2007 levels by 2050 . For that, some of the strategies are to stimulate growth in centres and transit corridors; promote working and playing close to home; encourage transit, cycling and walking; adopt green infrastructure; established mix-used transitoriented communities; and reduce vehicle kilometres travelled (Metro Vancouver Regional District, 2011[5]).

One of the goals of the RGS is to create a compact urban area delineating urban versus non-urban areas through an Urban Containment Boundary. Under this scheme, urban centres throughout the region will be served by transit and the road network. The urban centres should be locations for employment and convenient access to shops and services close to home. FTDAs provide an additional focus for growth, particularly for higher density residential, commercial, and mixed use development. The urban centres and the FTDAs help shape transportation demand and optimise investments in the MVR transport system. Similarly, the RTS aims to contribute to Metro Vancouver's Integrated Air Quality and Greenhouse Gas Management Plan by creating and supporting a cleaner, more efficient transportation system.

\section{Planning at local level - a framework for managing change}

Under the provincial Local Government Act, all municipalities must develop one or more social, economic and physical plans. Indeed, the different municipalities that form part of the MVR develop their own 'official 
community plans' (OCPs). The OCP is a long-term vision for future community planning by describing the kind of community into which the city wishes to evolve (see for example Box 3 on the vision of the City of Richmond). The OCP constitutes a guiding document for the City Council in future decision-making, ranging from short- to long-term investments, programming, and land use changes. It also provides a broad framework for managing change including policies to address related needs for amenities, services and infrastructure. The OCP must be in line with the RGS and, in general, they specify how it will contribute to the achievement of the RGS goals.

\section{Box 3. The Vision for a Sustainable City of Richmond}

The 2041 Official Community Plan of the City of Richmond states that the city's future should be guided by the following vision:

"A sustainable and healthy island city that meets the needs of the present without compromising the ability of future generations to meet their own needs. It is a place where people live, work, and prosper in a welcoming, connected, accessible and vibrant community. In Richmond, the health of the people and the health of the eco-system are sustained through community participation and long-term economic, social and environmental well-being."

Source: City of Richmond (2012[20]).

The OCPs must address how the city will accommodate anticipated housing needs (including affordable housing, rental housing and special needs housing) over at least a period of five years, and designate the approximate location for various economic and recreational land uses. The plans must also include the approximate location and phasing of any major road, sewer and water systems, as well as the approximate location and type of public facilities. Inclusion of social, environmental and agricultural policies is optional. For example, the OCP of the City of Coquitlam (139 000 inhabitants in 2016) includes policies on developing complete communities, a healthy environment, housing, economic development, transport, infrastructure and community services. They also plan for the implementation and monitoring of those policies. ${ }^{6}$ Box 4 shows the strategic transport objectives of Coquitlam's OCP, which reflect a strong linkage between land use, housing and transport. In the MVR, municipalities are required to include a Regional Context Statement indicating how each municipality's OCP relates to and works towards supporting the regional plan's goals. ${ }^{7}$ Thus, all OCPs should aim to enable the development of transit-oriented communities. An OCP is used by residents, property owners, community groups, developers and investors to learn about where and how future growth (for example, land use, density, architectural character) may occur and then make decisions and prepare development proposals based on it.

\section{Box 4. Coquitlam Citywide Official Community Plan: Strategic Transport Objectives}

The Transit-Oriented Development Strategy (TDS) of Coquitlam provides a set of citywide objectives for the Evergreen SkyTrain line corridor. The objectives are in line with the Citywide Official Community Plan. Achieving these objectives is crucial to creating successful TODs in Coquitlam:

1. Create compact, complete neighbourhoods: the goal is to ensure land around rapid transit stations develops as a focused hub of mixed-use activities and services that benefits the local community by providing employment opportunities, retail needs, and a variety of housing options. 
2. Develop transit supportive density: the goal is that developments around stations should be notably higher in density than the surrounding community in order to promote transit ridership and support viable retail and service uses.

3. Implement high quality urban design: the goal is to create a visually interesting and functional environment that adds to the vitality of a Transit-Oriented Development area.

4. Create great places: the goal is to support the provision of improved or new community amenities in transit station areas in order to serve local needs and create attractive destinations.

5. Promote sustainable transportation choices: the goal is that TOD areas should foster greater connectivity locally and regionally through the promotion of sustainable transportation choice and well-designed streets.

6. Manage parking: the goal is to support TOD through effective parking management, seeking an appropriate level of supply through private development in areas well served by public transport.

Source: Coquitlam City (2017[21]).

Across the regional strategies and the different municipal OCPs, a key transport concept that is present is the Frequent Transit Network (FTN). The FTN is a concept that identifies corridors linking urban centres and other key activity areas with high-frequency, high-quality service. Whether served by bus, rail, or ferry, FTN corridors - and especially the nodes where these corridors intersect - are important places for the region to direct growth and development. Hence, the FTN has become an important organising framework in MVR for coordinating land use and transport policies (TransLink, 2012, p. $8_{[16])}$.

The OPCs are at the top of the hierarchy of land use plans and they normally include more specific area plans and neighbourhood plans. If there is a conflict between the OCP and the area plan, the area plan takes precedence over the citywide policies. Local councils are not obliged to strictly implement the policies of OCPs; the plans may be amended from time to time, but the important requirement is that every amendment must go through a public consultation process that includes a formal public hearing. 


\section{The regional transport strategy}

\section{Investing in transport and residents' well-being}

Part of the success of the Metro Vancouver region as one of the best places to live in the world 8 has been its investment in transport infrastructure. MVR has an integrated transport system that offers different options for moving around the metropolitan area: bus, SkyTrain, SeaBus, and West Coast Express (Figures 2 and 3). The SkyTrain, one of the oldest and longest automated driverless light rapid transit systems in the world, has three lines that connect several municipalities with the City of Vancouver. The Expo (opened in 1985 for Expo 86) and Millennium (opened in 2002) lines connect the city of Vancouver to the cities of Burnaby, New Westminster, Surrey, Port Moody and Coquitlam whereas the Canada line (opened in 2009 for the 2010 Winter Olympics) connects the city of Vancouver to the city of Richmond and the Vancouver International Airport. ${ }^{9}$ The Millennium Line's Evergreen extension, opened in 2016, connects the cities of Port Moody and Coquitlam to the existing SkyLine system, regional bus network and West Coast Express. This is a long-term transport infrastructure investment and it is seen as a key building opportunity for the city. The entire transport network moved 247 million passengers around the region in 2017. More than half of all dwellings and two-thirds of jobs are located within walking distance of the FTN (Mayors'Council on Regional Transportation, 2017, p. $\left.1_{[15]}\right)$.

MVR's public transit system is leader in the country regarding the growth in the proportion of ridership. Indeed, MVR is among only four urban areas in the US and Canada with populations over one million which saw ridership growth in 2017 (5.7\%). The other urban areas that experienced growth in ridership were Phoenix (3.5\%), Seattle (2.3\%) and Montreal (2.3\%) (TransLink, 2018[22]). MVR's transit ridership has historically been higher than many comparable regions in Canada and the US as a result of decades of transit-friendly land-use and transportation policies, including an early regional goal to foster density only around the network (Yuen, 2018[23]). According to TransLink (2018[22]), factors such as economic growth in the region, high gas prices and the addition of the Millennium Line Evergreen Extension have contributed to this growth. 
Figure 2. Metro Vancouver Frequent Transit Network

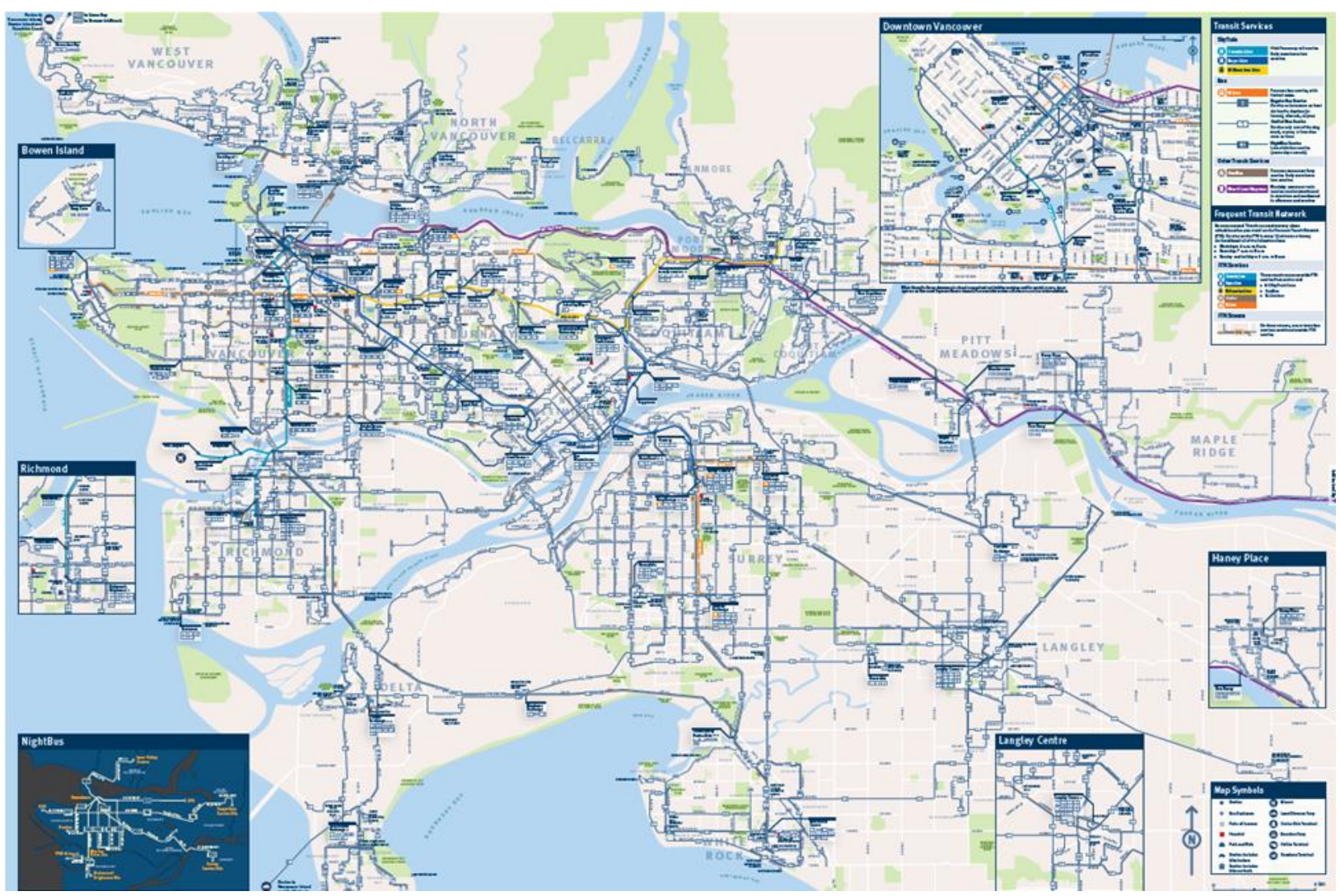

Source: TransLink http://infomaps.translink.ca/System_Maps/146/MVTM-September2018.pdf

Figure 3. Key regional transit connections in MVR

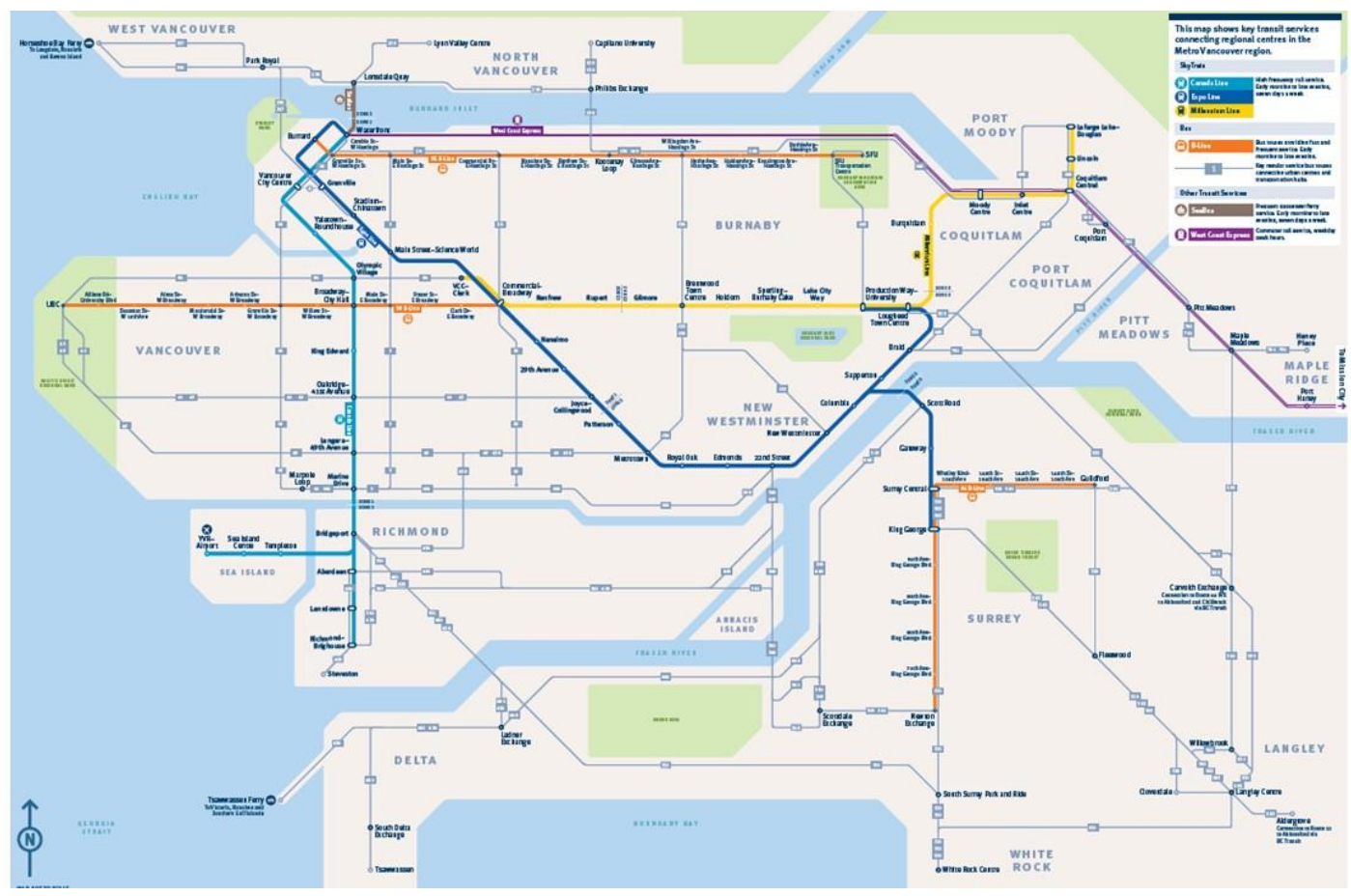

Source: TransLink, http://infomaps.translink.ca/System_Maps/KRTC.pdf 
Job location is a factor that influences the amount of time spent in transit. In MVR all but two sub-regions have a majority of employed commuter residents travelling outside of their home region for work (Metro Vancouver, 2015, p. 10[9]). However, despite investments, all but two subregions in MVR have a majority of employed commuter residents travelling outside their home subregion for work (Table 3). That is why, the RGS aims to encourage more jobs to be located where people live.

Table 3. Share of commuters working outside home subregion, 2011

\begin{tabular}{lrrr}
\hline Home subregion & $\begin{array}{c}\text { Share of commuters } \\
\text { working outside home } \\
\text { subregion }\end{array}$ & $\begin{array}{c}\text { Share of commutes by } \\
\text { auto as driver or } \\
\text { passenger }\end{array}$ & $\begin{array}{c}\text { Share of commuter trips } \\
\text { by transit }\end{array}$ \\
\cline { 2 - 4 } Delta & 70 & 84 & 14 \\
Northeast sector & 64 & 77 & 20 \\
Pitt Meadows / Maple ridge & 61 & 84 & 14 \\
Burnaby / New Westminster & 61 & 64 & 34 \\
Langley city and Township & 54 & 94 & 4 \\
Surrey / White Rock & 53 & 81 & 17 \\
North Shore & 53 & 73 & 22 \\
Richmond & 45 & 73 & 25 \\
Vancouver & 32 & 67 & 28 \\
\hline
\end{tabular}

Note: Data excludes residents working at home or with no fixed work address.

Source: Metro Vancouver (2015[9]).

At metropolitan level, however, it is estimated that approximately 6.06 million daily trips are made on a typical fall weekday in 2011 ; this is an increase of $9.2 \%$ compared to 2008 . This is the result of a combined effect of a $6 \%$ increase in population with a $3 \%$ increase in the average trip rate (TransLink, 2013[24]). The number of trips by MVR residents translates to a daily average of 2.77 trips per person versus 2.68 in 2008 (TransLink, 2013[24]). It is worth noting that in the City of Vancouver, although the car is still king, public transit is more widely used by students (Figure 4). It would be interesting to see if this tendency translates into a wider use of sustainable transport means in the years to come.

Figure 4. Usual mode of travel to commute in the city of Vancouver, 2017

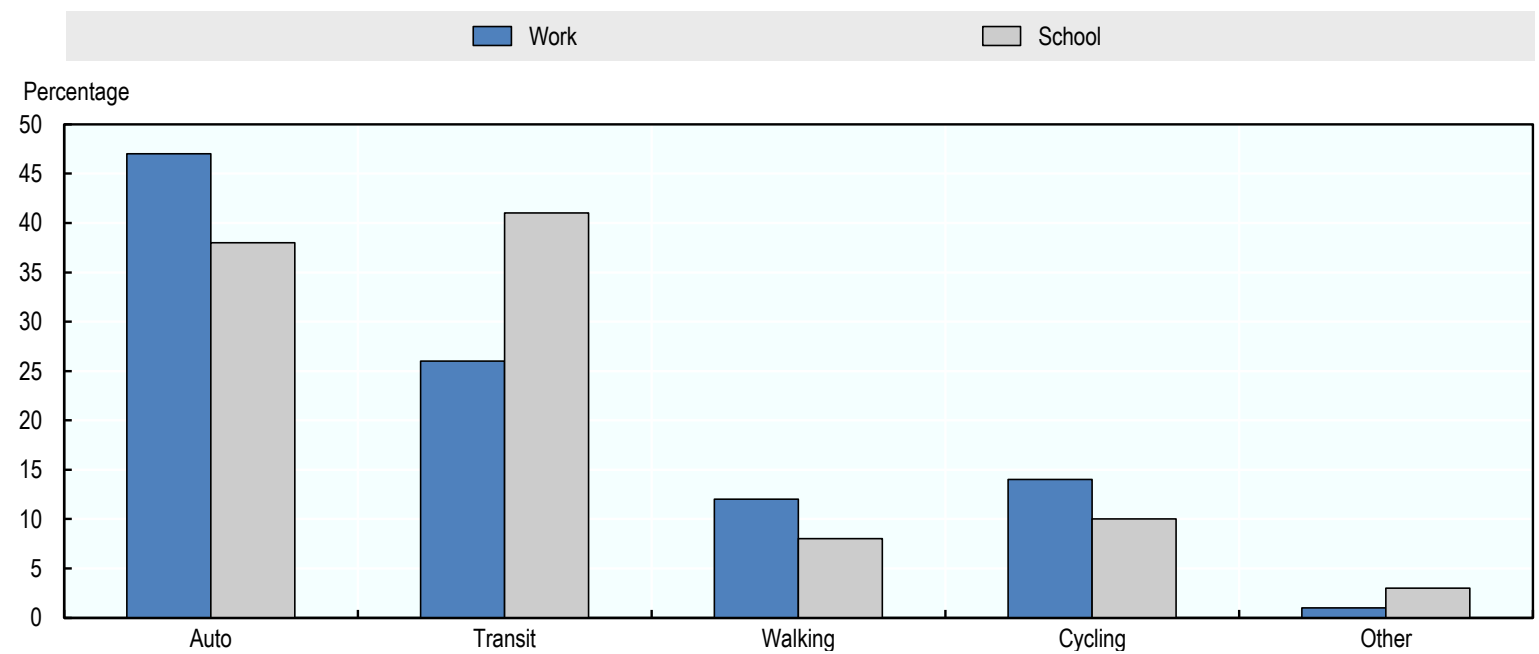

Source: McElhanney $\left(2018_{[25]}\right)$. 
The transport vision for the region is to meet all the transport needs in a way that enhances the health of the people, communities, economy and environment so as to maintain the high living standards that residents in the region enjoy (Box 5) (TransLink, 2013[17]). However, a growing and ageing population, a limited geographical area, rising energy prices, and evolving vehicle technology amid a backdrop of tighter budgets add to the challenges of the metropolitan region.

The goal of the RTS is to make transport decisions that: i) provide sustainable transport choices; ii) support a compact urban area; iii) foster safe, healthy and complete communities; iv) enable a sustainable economy; and v) protect the environment. The vision is to build a robust transportation network that provides residents with a range of convenient and accessible mobility options and build a competitive regional economy. For that purpose, regional and local authorities work on supportive measures such as: transit-oriented land use, transit priority measures, better parking management, and walking and cycling investments (Mayors'Council on Regional Transportation, 2017[15]).

Transit investments include the addition of 400 conventional buses and mini-buses to the existing fleet of 1,830 buses, and adding a total of 1.45 million annual bus service hours, an increase of $25 \%$ compared with today's bus levels. It is expected that in total transit hours, bus and rail service will expand by more than one-third over the next ten years. Many more people are expected to rely on transit as a convenient and competitive travel option regardless of where they live.

\section{Box 5. TransLink's definition of sustainable transportation system}

A sustainable transportation system is one that:

- Allows the basic needs of individuals and societies to be met safely and in a manner consistent with human and ecosystem health, and equitably both within and between generations;

- Is affordable, operates efficiently, offers choice of transport mode, and supports a vibrant economy;

- Limits emissions and waste within the planet's ability to absorb them, minimises consumption of non-renewable sources, limits consumption of renewable sources to the sustainable yield level, and reuses and recycles its components; and,

- Minimises impact in terms of land use and noise pollution.

Source: TransLink Sustainable Policy - creating a more sustainable future, accessed at: www.translink.ca//media/Documents/about_translink/corporate_overview/policies/sustainability_policy.pdf?la=en\&hash=7D844CFD69D87879784160DC6C 3F9BBF4700093A.

\section{Sustainability, low-cost and distance reduction at the core of the strategy}

The RTS has two main strategic objectives. The first one is for half of all trips to be taken by walking, cycling and transit which are the lowest-cost and lowest-impact forms of transportation, and require the least amount of land. In 1985 only 19\% of trips were made on foot, by bike or public transit; in 2011 the share increased to $27 \%$, but the target is $50 \%$ across the region by 2045 . Critically, the RTS considers the uniqueness of each municipality in the region as they will have different levels of walking, cycling and transit based on their context, location, infrastructure and stage of development.

Another important target of the RTS is to reduce the distance people drive by one-third. This target depends on the region's success in getting people closer to jobs and services, which can be done by minimising the distance and time people and goods have to spend travelling. The reasoning is that if homes, workplaces 
and services are closer together, it will be easier and more convenient for people to walk, cycle, take transit and arrange carpooling and car sharing. Promoting accessibility is expected to make people and goods spend less time commuting, save energy, reduce costs and inconvenience, improve quality of life, protect the environment and support economic development (TransLink, 2013 $\left.{ }_{[17]}\right)$. The master transportation plans of the different cities also reflect a long-term vision on how transport can contribute to compact, safe and liveable neighbourhoods supporting a mixture of functions and activities. For example, Box 6 presents the transportation vision of the city of New Westminster that was developed from the input received from residents, and other stakeholders.

\section{Box 6. The transportation vision of the city of New Westminster}

"New Westminster's multi-modal transportation system will support the development of a compact, sustainable and resilient community, maintaining the city's role as an important historic centre and economic hub within the region, while ensuring that New Westminster's diverse neighbourhoods are healthy, active, liveable and vibrant."

Source: City of New Westminster (2014[26]).

In seeking to reduce those travel distances and to increase the likelihood that trips can be made by walking, cycling or transit, TransLink is aligning transport infrastructure and services more closely with land use decisions that are the responsibility of Metro Vancouver, local governments, the Port and Airport authorities. The premise is that when the transport system performs well, individuals and businesses reap direct economic benefits, if it falls short the region will lose productivity and citizens will lose opportunities for personal fulfilment. Moreover, the Regional Transportation Strategy is also contributing to the British Columbia Climate Action Plan goals by creating and supporting a cleaner, more efficient transport system. ${ }^{10}$ Figure 5 shows the transportation hierarchy in the City of New Westminster that helps to identify priorities and resolve trade-offs. This hierarchy promotes a shift in transportation patterns but it does not imply that one mode will always be prioritised over another, but rather that the needs of each mode should be explicitly considered in the order presented as part of the decision-making process. This hierarchy gives priority to pedestrians including those using mobility aids such as wheelchairs, as well as cyclists, public transport and ride share. Although Figure 5 illustrate the transportation hierarchy in one municipality in the MVR, it can illustrate the general approach in the region. 
Figure 5. Transport hierarchy

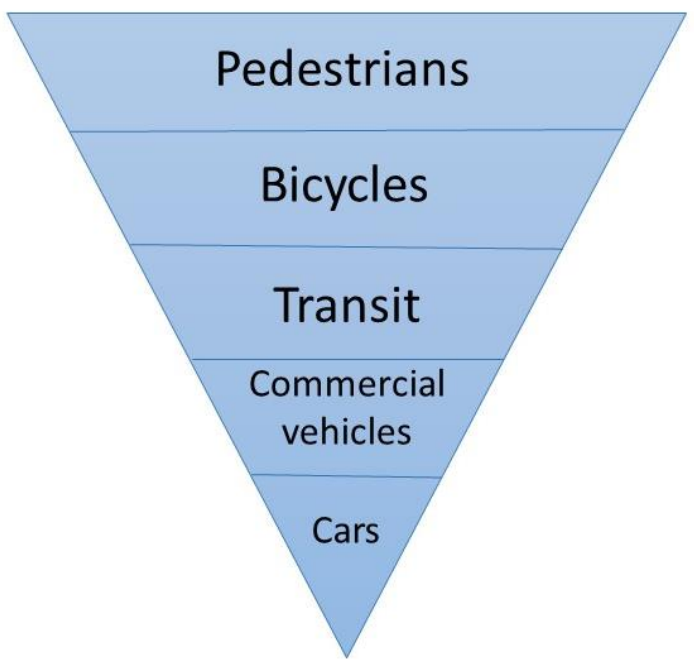

Source: Based on City of New Westminster (2014[26]).

The RTS acknowledges that when the transport system performs well, individuals and businesses reap direct economic benefits. However, when it performs poorly, there is a loss of productivity, foregone transactions, and lost opportunities for personal fulfilment.

\section{Rethinking transport to foster accessibility}

To deliver the RTS, TransLink needs to invest strategically to maintain and expand the transport system (TransLink, 2013[17]; Mayors'Council on Regional Transportation, 2017 ${ }_{[15]}$ ). For that, investment decisions are made in tandem with decisions on land use and demand management. The key issue is to ensure that new projects enhance goods movement and travel time reliability without increasing general purpose traffic. Therefore, it is critical to understand what land uses are in place and current and future demand. Where basic networks are incomplete or supply is insufficient to meet demand, decisions on the expansion are made in a way that promotes regional goals as cost-effectively as possible. TransLink has noticed that infrastructure alone cannot resolve transportation problems, especially if new infrastructure acts to encourage people to travel farther or more frequently.

For evaluating cycling, road and transit initiatives against a common set of goals and then giving priority to the most effective combination of solutions, TransLink uses a performance-based planning approach. So far, it is argued that the result has been a more efficient use of taxpayers' money and has improved transparency in decision-making and investment choices.

Despite tight financial resources, one of TransLink's priorities is to provide maximum value with the existing assets while working with its partners (Metro Vancouver, municipalities, higher levels of government, etc.) to make future investment decisions in a way that is more integrated and considers all possible solutions. For instance, to resolve traffic bottlenecks, TransLink and the Mayors' Council are currently considering a combination of actions including increasing transit capacity and exploring more dynamic mobility pricing for both the road and transit system. These solutions would help MVR manage demand better. Table 4 presents some of the strategies and key actions on transport investment as detailed in the RTS. It shows the focus on maintaining the existing infrastructure and expanding the transportation system. 
Table 4. Strategic transport investment - key actions

Actions outlined in the Regional Transport Strategy

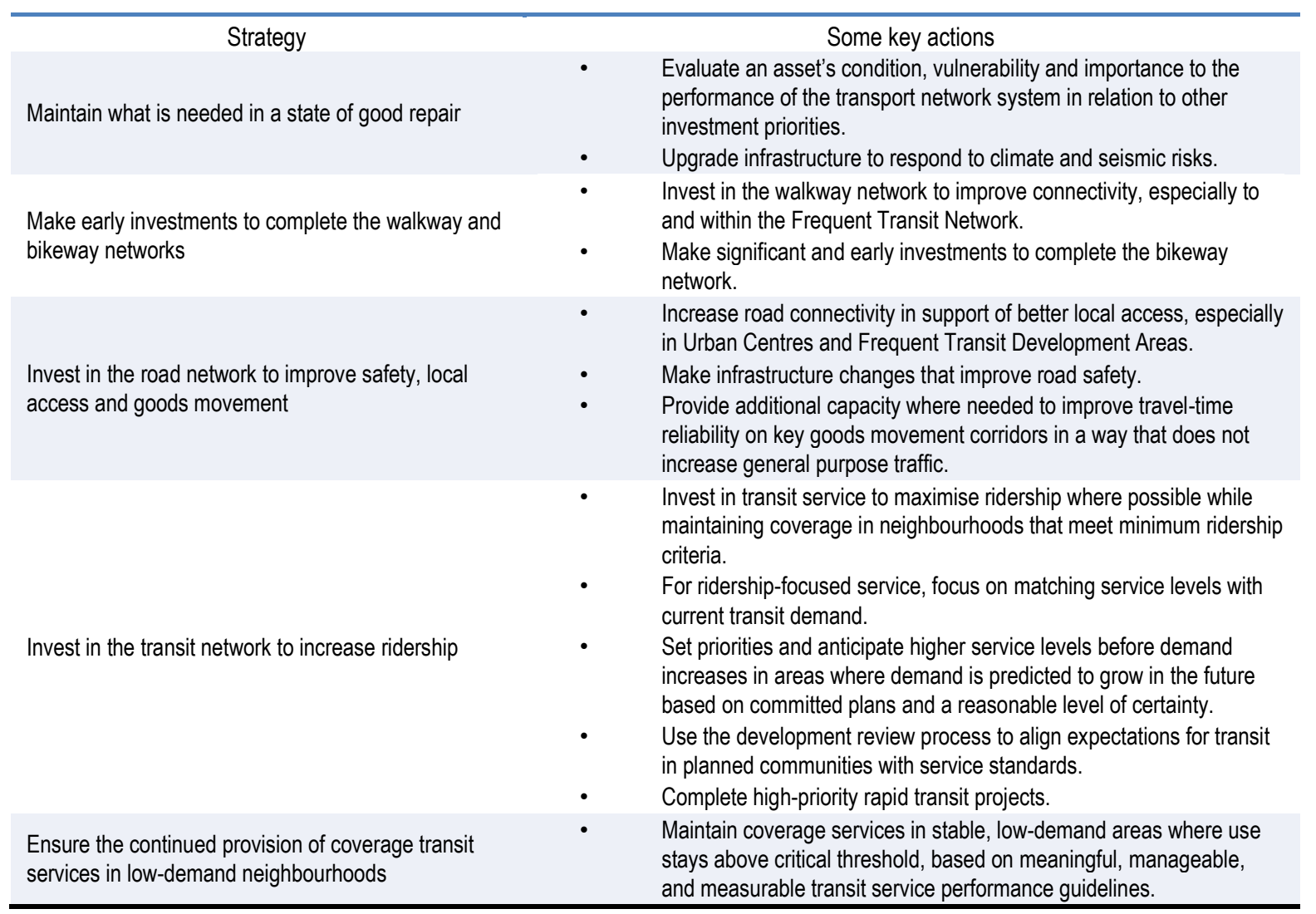

Source: Based on TransLink (2013[17]).

\section{Investing in cycling and walking infrastructure is essential to achieve the region's accessibility goals}

Walking and cycling are considered the investment areas that can contribute the most to achieving MVR's strategic goals like reducing congestion and improving public and environmental health, at the lowest net cost. To unlock cycling's potential the region and municipalities are investing in traffic-protected bikeways that provide the safety and comfort needed. They are also improving sidewalks, street crossings and other walking infrastructure to remove barriers and expand walking access to transit. However, there are municipalities such as the cities of Surrey and New Westminster where many neighbourhoods, mainly rural ones, do not have walking infrastructure. Indeed, in many places in the region, poor walking connectivity to the FTN and rapid transit stations is deterring ridership and making those investments less productive than they could otherwise be. TransLink is working with the different municipalities to share the costs of pedestrian facility upgrades within walking distance of frequent transit stops, stations and exchanges. Some of the actions cities are taking include: enhancing sidewalk maintenance, repaving, improving quality of surfacing, sidewalk widening, increasing accessibility, providing buffers or boulevard between pedestrians and vehicles, and removing obstructions. The idea is to create a safe, comfortable and attractive walking environment (City of New Westminster, 2014[26]).

Developing a network of high-quality bike lanes is a work in progress. Some residents in some municipalities such as Vancouver are still not convinced of the need for this infrastructure. ${ }^{11}$ TransLink is coordinating the development of the network across municipal boundaries and its integration with transit. 
The plan is to promote cost-sharing to support the building of the network and fully funding a programme to develop secure bicycle parking at TransLink-owned facilities region-wide.

The partnership with municipalities is facilitating the integration of cycling and walking with transit in the areas adjacent to transit stops, stations and exchanges through minor improvements and more comprehensive land-use and station area plans. However, completing the bikeway network is a long-term project for the next 25 years.

Table 5 presents the progress made so far regarding the implementation of Phase One of the 10-Year Vision for Metro Vancouver Transit and Transportation up to 2018. Although the resources actually allocated to municipalities still appear minimal relative to the full commitment to improving cycling and walking infrastructure, it is expected that all targets outlined in Phase 1 will be met by the end of the plan period.

\section{Table 5. 10-Year Vision: progress on delivering Phase One}

Progress on walking and cycling investment projects

\begin{tabular}{|c|c|}
\hline Phase 1 projects & What has been delivered so far \\
\hline $\begin{array}{l}\text { CAD } 12.5 \text { million in new funding over } 3 \text { years for municipalities } \\
\text { to improve pathways around transit, like sidewalks, } \\
\text { crosswalks, and pedestrian traffic signals. }\end{array}$ & $\begin{array}{l}\text { CAD } 2.5 \text { million allocated in } 2017 \text { to municipalities to improve } \\
\text { pathways around transit, like sidewalks, crosswalks, and pedestrian } \\
\text { traffic signals. }\end{array}$ \\
\hline $\begin{array}{l}\text { CAD } 29.8 \text { million in new funding over } 3 \text { years for municipalities } \\
\text { to encourage and improve cycling through projects like building } \\
\text { bike lanes and multi-use paths. }\end{array}$ & $\begin{array}{l}\text { CAD } 6.9 \text { million allocated in } 2017 \text { to municipalities to encourage and } \\
\text { improve cycling through projects like building bike lanes and multi- } \\
\text { use paths. }\end{array}$ \\
\hline $\begin{array}{l}\text { CAD } 11.5 \text { million in new funding over } 3 \text { years to improve } \\
\text { regionally-owned cycling facilities around major transit stations } \\
\text { and exchanges }\end{array}$ & $\begin{array}{l}\text { In process of prioritising capital projects to improve regionally-owned } \\
\text { cycling facilities. }\end{array}$ \\
\hline
\end{tabular}

Source: TransLink (2018[13]).

\section{Better transport management leads to better investment returns}

Managing the transport system to make it more efficient and user-focused is another key strategy to realising MVR the region's transport vision. The MVR transport system already offers users an array of choices for every trip. The RTS considers that to help people and businesses make choices that are best for them and for the transport system, it is necessary to have excellent design, regulation and pricing as well as making information available to the public. TransLink is of the view that government subsidising of roads and transit tends to skew usage as it is difficult or impossible for individuals to understand the true cost of their travel choices. Consideration has been given to implement or expand three kinds of price signals: road pricing; transit pricing with time-of-day, location or distance-travelled variations; and parking pricing. All of these pricing strategies would be designed to manage demand, for example, by giving drivers or transit riders an off-peak discount to help alleviate bottlenecks at busy times of the day, or by finding a price point that ensures parking is always available to those who need it, and not clogged by those with a convenient and more affordable alternative. Technology and supply-management solutions can also make the transport system more space and energy-efficient (ITF/OECD, 2020[1] ). Table 6 presents the strategies and some of the key actions to make the transport system more efficient and user-focused. It shows that authorities in MVR are trying to reach a balance between fairness, efficiency, safety and revenue. 
Table 6. Strategic actions for the more efficient and user-focused public transport system

\begin{tabular}{|c|c|}
\hline Strategy & Some key actions \\
\hline Make travel safe and secure for all users & $\begin{array}{l}\text { - Support laws, enforcement, skills, training and designs that improve road safety } \\
\text { and protect the vulnerable. } \\
\text { - Use physical design and enforcement to deter crime. } \\
\text { - Be prepared to respond effectively in the event of natural disasters and other } \\
\text { emergencies }\end{array}$ \\
\hline Make travel easy and attractive for all users & $\begin{array}{l}\text { - Design to maximise accessibility for people of all ages and abilities. } \\
\text { - } \quad \text { Support carsharing, ridersharing, bikesharing and taxis by researching how best } \\
\text { to increase trips by multiple-occupancy vehicles. } \\
\text { - Develop regional and sub-regional targets for multiple-occupancy vehicle trips. } \\
\text { Provide incentives, information and support programmes to help make travel } \\
\text { easier. } \\
\text { Make the transportation system easy to understand and navigate, with a } \\
\text { consistent region-wide wayfinding system and real-time travel information for all } \\
\text { modes. }\end{array}$ \\
\hline $\begin{array}{l}\text { Optimise roads and transit for efficiency, } \\
\text { safety and reliability }\end{array}$ & $\begin{array}{l}\text { - Integrate an intelligent transport system, incident management, road works } \\
\text { management, lane management and signal priority for goods and transit. } \\
\text { Explore opportunities and potential impacts of new vehicle technologies } \\
\text { including low carbon, connected and self-driving automobiles. } \\
\text { - Reallocate road space to improve capacity, safety and reliability for walking, } \\
\text { cycling, transit and goods movement. } \\
\text { - Continue to reallocate savings from system efficiency measures into initiatives } \\
\text { that most cost-effectively achieve regional transport goals. }\end{array}$ \\
\hline $\begin{array}{l}\text { Use integrated mobility pricing for fairness, } \\
\text { efficiency and revenue }\end{array}$ & $\begin{array}{l}\text { - Adopt a mobility pricing strategy to make transport pricing decisions in an } \\
\text { integrated fashion considering all modes of travel. } \\
\text { - Link pricing decisions to invest commitments and introduce changes in mobility } \\
\text { pricing in tandem with the introduction of major transport investment. } \\
\text { - Consistently apply mobility pricing to the transit system and to the road system to } \\
\text { allow for more granular variation in prices based on time, distance travelled or } \\
\text { location. } \\
\text { - Develop a multi-agency strategy to improve affordable access to transport to the } \\
\text { economically vulnerable. } \\
\text { Monitor and, where necessary, adjust pricing implementation to protect system } \\
\text { access for those who have no options to change their transport behaviours. }\end{array}$ \\
\hline $\begin{array}{l}\text { Manage parking for fairness, efficiency and } \\
\text { revenue }\end{array}$ & $\begin{array}{l}\text { - Install sufficient bicycle parking in urban centres and Frequent Transit } \\
\text { Development Areas. } \\
\text { Ensure that automobile parking requirements are not excessive and reflect } \\
\text { availability of walking, cycling, transit, taxi, car sharing, and carpooling options, } \\
\text { local demographics and housing type. } \\
\text { - Support separating the cost of parking from the cost of the unit (house, building) } \\
\text { so that people and businesses have the opportunity to save money if they do not } \\
\text { need the parking space. } \\
\text { - Use pricing and/or time limits to make most efficient use of on-street and off- } \\
\text { street parking in Urban Centres and Frequent Transit Development Areas. } \\
\text { Facilitate area-wide parking management and other opportunities for shared } \\
\text { parking. }\end{array}$ \\
\hline
\end{tabular}

Source: Based on TransLink (2013[17]). 


\section{Transit-oriented affordable housing}

\section{A new way of looking at affordability: housing + transport costs}

The Metro Vancouver Region is one of the most expensive places to live in Canada (Metro Vancouver, $\left.2015_{[9]}\right)$. It has the highest average monthly costs for homes with a mortgage and one of the highest monthly rents in the country. Working households in the MVR can spend up to one-half of their pre-tax income on housing and transportation costs. Following transportation, the lack of affordable housing is one of the most frequently mentioned issues that is of growing concern for citizens. There is an estimated yearly shortfall of 2400 housing units in the MVR that are affordable to lower income households (Metro Vancouver, 2019[27]). The cities of Vancouver and North Vancouver have had the greatest success in promoting pedestrian-friendly programmes, but they also face the toughest challenges in terms of housing affordability not only in terms of social housing but also in attainable housing for the middle class (OECD, $\left.2012_{[3]}\right)$. In the City of Coquitlam, for instance, traffic congestion $(21 \%)$ and housing costs/affordable housing (10\%) are among the top three culprits that affect quality of life (Ipsos, 2017[11]). Indeed, when housing and transportation costs are combined, the cost burden relative to the median income is $40 \%$ for owners and 49\% for renters (Metro Vancouver, 2015, p. 14[9]). Metro Vancouver's working households earn $83 \%$ of what households make in Calgary, but face $9 \%$ higher housing ownership costs, and pay nearly the same rent (Metro Vancouver, 2015, p. 8[9]). OECD (2012[3]) has found that although some families are moving into the downtown core, a large fraction of the young adult population is leaving the MVR for more affordable communities. Culturally, residents are more inclined to own rather than to rent, and many feel uncomfortable paying high mortgages or high rents for small condominium apartments.

\section{Figure 6. Housing and transportation cost burden, 2015}

Working owner household with mortgages

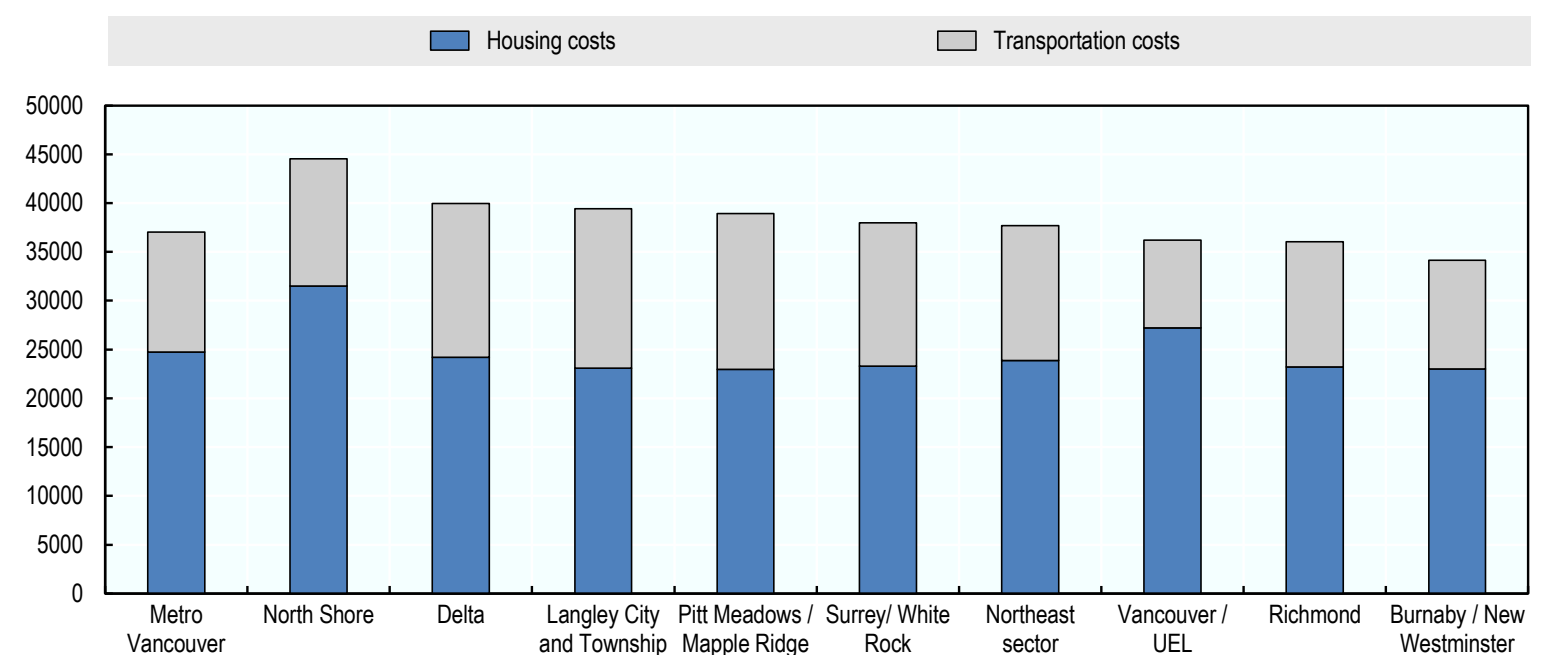

Note: Housing costs represent average payments for all homes owned by working households with mortgages. Transportation cost estimates are representative of all working households.

Source: Based on Metro Vancouver (2015[9]). 
Since housing and transportation costs are closely linked and represent the two largest expenditures for many working households, they need to be considered together when analysing affordability. Coordinating transport and housing policies increases the possibility of a city being more inclusive and have more holistic policies. So far, the federal government has not put in place any provisions regarding affordable housing. The provincial government of British Columbia has dabbled with rapid transit development but has yet to implement any detailed programmes.

MVR has the challenge of building new rental housing, particularly housing that households earning less than CAD 50000 per year (USD 37350 approximately) can afford and that are located in neighbourhoods with access to public transport across the region. ${ }^{12}$ The metropolitan area needs 114000 new affordable housing units but there is no space available for construction. Currently, demand for rental housing is not being met across MVR. Renters, especially households earning less than CAD 50000 per year, are more likely to use transit. Increased ridership means higher return on investment in public transport. The basic premise is that access to frequent transit reduces transport costs and improves access to services and employment. One of the main reasons why new affordable housing is undersupplied in the region is because the rents (CAD 1300 a month on average or USD 970 approximately) do not cover the costs of development (land and construction). The problem is exacerbated in transit-oriented locations because the higher density development expectations increase the land costs (MetroVancouver, 2017[28]). The most expensive housing markets are located in high density residential condominium and commercial developments with access to rapid transit stations. Low and moderate income households cannot afford to buy or rent in new condominium units in these locations (Metro Vancouver, 2015[9]). High housing and transportation costs together make MVR less competitive as it is more challenging to attract and retain a qualified workforce to sustain the economy compared with other regions in the country such as Calgary and Ottawa, which have lower annual monthly housing costs and higher household incomes.

Metro Vancouver's RGS calls for more density near transit hubs and urban centres to reduce reliance on cars, promote neighbourhood walkability, and house the one million newcomers expected by 2040 . Higher density development areas are located close to SkyTrain stations within a perimeter of 400 metres. The plans consider commercial and residential areas but sometimes it is challenging for local authorities to attract new office uses due to the lack of amenities like in Surrey. The suburbs of some cities need to be retrofitted as they are very car-oriented and lack public transit infrastructure. Improving the frequency of the bus service is seen as one solution, but improving bike lanes as part of road-widening works is another solution to enhance accessibility. The municipality of Surrey, due to its size (the $2^{\text {nd }}$ largest in MVR) has town centres too spread out, which should be connected among themselves in a better way. However, it needs to move away from the road space approach to include other types of infrastructure such as bike lanes that are not currently being considered. Sidewalks are missing in many areas for single familyhomes. Sidewalks were provided only after 1980 s as before it was not a requirement for development. In other municipalities of the region such as Coquitlam, more housing types are needed, not just skyscrapers and single family homes, but gradations and transitions between them.

Densification has come at a cost in the MVR. The price of housing close to transit areas is raising to the point such that only the people who can afford to live near transit are the least likely to depend on it (Hyslop, $\left.2015_{[29]}\right)$. Moreover, only a few cities in MVR already require residential developers to include community amenities like affordable units in new projects. The problem is that developers can often negotiate what amenities they will provide, including affordable housing, in a case-by-case process and they are the ones who, in the end, decide the amount of affordable housing. For instance, it was expected that the Vancouver Olympic Village would have 700 of the 1100 housing units as social housing, but in the end the number was reduced to 126 units (Hyslop, 2015[29]). 


\section{Tackling the affordable housing challenge via transport investment}

Households make trade-offs when choosing where to live based on their personal preferences, housing price, neighbourhood character, quality of services and amenities, and proximity to work and school. Proximity to the FTN is an additional criterion. In addition to expanding the FTN, concentrating new growth and development around existing FTN corridors will also help give more households an option to be less auto-dependent and reduce their transport expenditure, which is a similar approach taken in cities such as Paris and London. To meet the challenge, MVR plans to build new rapid transit lines, new B-line bus corridors, and more frequent bus routes throughout the region. The aim is to expand the transit-oriented locations to make the connection between transit and affordable housing. But partnerships and concerted efforts are necessary to make affordable housing a reality. Moreover, TransLink and Metro Vancouver would need to consider whether extending the transport network alone would be enough and whether that is financially sustainable. Considering location and transport accessibility in selected sites for affordable housing may help create connected communities.

In 2019, Metro Vancouver completed Phase 2 of the Transit-Oriented Affordable Housing Study. It expands the knowledge base about the effectiveness, limitations, and applicability of specific tools to support the delivery of transit-oriented affordable housing supply in the region. ${ }^{13}$ One tool under consideration is a regional transit-oriented affordable housing fund to provide low-interest loans to help finance new affordable rental housing in the region (Metro Vancouver, 2019[27]). This tool would support policy goals on integrating transit and affordable rental housing. However, the options discussed in Phase 2 do not seem to include options to ensure that affordable housing remains affordable over the long term. Expanding the transport network to areas not well-served may in fact lead to affordable housing becoming less affordable. There do not seem to be any requirements to assess the spillover effects of transport expansion in housing prices. Affordable housing in prestigious neighbourhoods is very limited, though pressure on municipalities to increase residential density near main transit lines is growing. Rents are cheaper in areas not close to transit zones, but the transport costs make them more expensive. 


\section{The governance framework for transport accessibility}

\section{Transport provision requires multi-level governance}

Ensuring sustainable transport and greater accessibility across the Metro Vancouver region requires a highly collaborative and coordinated process of policy and decision-making, as well as a clear division of responsibilities among actors from different sectors. Local government authorities are responsible for creating compact urban areas and getting jobs, housing and major trip generators in locations that shorten trips facilitate walking, cycling, and transit. Indeed, local governments are in charge of local land use planning that is consistent with the RGS. Metro Vancouver and TransLink are key actors in the regional governance arrangements as they make important and expensive decisions on issues such as transport. On several occasions, both have been praised as being effective and innovative in meeting urban challenges (Krawchenko, 2012[7]).

Metro Vancouver is a political and corporate entity that is formed by the different local governments in the metropolitan area that plans for and delivers regional-scale services (drinking water, wastewater treatment and solid waste management). It also regulates air quality, plans for urban growth, manages a regional parks system and provides affordable housing. ${ }^{14}$ Through the Regional Growth Strategy, Metro Vancouver encourages the development of compact and complete communities that recognise the region's geographic and political boundaries and preserves natural and agricultural spaces. Metro Vancouver undertakes regional and land use planning in partnership with all local governments. It produces the regional management plans in the areas of: drinking water, regional parks, liquid waste, air quality, solid waste, regional growth and affordable housing. Metro Vancouver develops and stewards the RGS, conducts policy research and data analysis. It works closely with municipalities, TransLink, upper levels of government and other stakeholders to coordinate complex land use and transport decisions. The type of actors and the coordination among them shows that institutional and technical capacities and legal provisions for land use and transport planning in MVR are strong.

Despite its relevance, residents in the metropolitan region are not fully aware of what Metro Vancouver is or its purpose. Part of the problem is that there is no regional elected government and the council board is composed of the mayors of the different municipalities. However, although the Metro Vancouver Council Board members are not directly elected, accountability is maintained through the requirement that the Council members are elected officials (mayors), and its activities are bound by the objectives of the RGS.

Although local governments work in close coordination with Metro Vancouver and TransLink, achieving consistency across the region is often challenging. The reason is that Metro Vancouver has to make policy for the local level at the regional level, but municipalities are in charge of implementation based on their own plans and priorities. Individual municipalities are responsible for economic development; however, Metro Vancouver provides a range of services that supports the economic development of the region and tracks economic, land use and other planning data relevant to prospective and current businesses. 
TransLink is the regional transport authority and service provider in the Metro Vancouver region (Box 7). It has the responsibility and authority to provide the most efficient connections to make the region a highly functional area. TransLink i) develops and implements strategies, plans and policies and makes transport investments that fosters sustainable transport choices; ii) provides a diversity of transport services and pursues operation and design innovations that maximise the benefits to society, the economy, and the environment while minimising adverse impacts, locally and globally; and iii) develops a resilient transport system that can adapt to the region's changing needs while fostering the capacity to respond in challenging or exceptional situations (TransLink, n.d.[30]).

TransLink is also mandated to support regional land use objectives, including the RGS policies to focus growth in urban centres and FTDAs. The RTS acknowledges that monitoring and evaluation are essential to assess progress. To do so, however, good data is needed. TransLink has taxation authority (fuel tax portion, levies, project toll charges, property tax, motor vehicle charges, and small fees) and one-third of its revenues come from transit fares (Government of British Columbia, 1998[31]). These taxes require regular adjustments to ensure that the region pays its share of the costs of transport projects, while the rest comes from provincial and federal governments. In the past, some proposed increases in taxes or fees had to be approved via a referendum. For example, in 2015 citizens voted down an increase in the sales tax that would have supported the 10-year vision on transport. In 2010, amendments to TransLink revenue tools gave it the ability to increase the fuel tax rate. With limited financing tools, local governments continue to look for alternatives to the property tax as a major funding source for transportation improvements, which is an issue that transit systems across Canada struggle with (Krawchenko, 2012[7]). The provincial and federal governments provide capital contributions to major infrastructure projects, which funds expansion but puts stress on operational funding. In 2011, the Mayors' Council and the province announced a new funding formula that includes a $2 \%$ per litre increase in motor fuel taxes plus either a property tax increase averaging about CAD 23 per year (USD 17.1 approximately) for the MVR residential property or a new, long-term source of funding (Krawchenko, 2012[7]).

\section{Box 7. TransLink - the regional transport authority}

The South Coast British Columbia Transportation Authority (commonly known as TransLink) is the world's first multimodal regional transportation authority founded 1999 as an integrated, regional transportation authority. The need for multimodal functions, local/regional control, coordination of transportation and transit with land use plans, expansion of the system's capacity, and expanded and stable funding, and the need to increasingly tie revenue generation to 'place' (the principle of raising revenues where they are spent) were some of the reasons that led to the creation of TransLink.

TransLink's purpose is to move people and goods, and to support the Regional Growth Strategy and the air quality objectives and economic development of the region. It is responsible for planning, managing and operating the regional transportation system that supports Metro Vancouver's Regional Growth Strategy, air quality and greenhouse gas reduction objectives and the economic development of the region. Its vision is to make the Metro Vancouver region a better place to live by building on transportation excellence. The mission is to connect the region and enhance its liveability by providing a sustainable transportation network, embraced by communities and people.

TransLink is governed by the Mayors' Council on Regional Transportation and TransLink's Board of Directors. The Mayors' Council role is to approve the appointment of TransLink board membership (from a pre-approved shortlist of candidates) and to approve strategic plans involving taxation measures, transit fare increases and new borrowing. Moreover, TransLink has the right to formulate 'bylaws' and may recommend regulations required for the regional transportation system.

Source: TransLink (2013[17]); Metro Vancouver Regional District (2011[19]); Krawchenko (2012[7]). 
Other important actors in the transport domain include: the federal government and the province, other authorities and agencies, as well as residents, non-profit organisations and business associations. The federal government has jurisdiction and funding responsibilities with regard to issues such as trade and transport facilities (e.g., railways, ports and airports). The provincial government's remit extends to transport planning, education and health facilities, all of which have significant impacts on land use patterns.

\section{Creating partnerships to make integrated policy transport solutions}

Regional transport requires coordinated and collaborative efforts from many stakeholders including TransLink, Metro Vancouver, and the different municipalities, upper levels of governments, the private sector, community organisations, and residents. These actors form partnerships to align land-use and transport planning to ensure that homes, work places and industrial areas are arranged in such a way that people and goods do not have to travel long distances. The partnerships work to ensure that road and transit investments are made according to the specific land use context. Indeed, these investments are made along corridors where the connections are in place to make cost-effective investments. TransLink has a unique position to coordinate efforts to establish partnerships and to promote and support reciprocal commitments to deliver the policy measures, land use changes and investments needed to get the best performance of the system. TransLink's relationship with Metro Vancouver today is less hierarchical than when TransLink was created and more consultative in orientation (Krawchenko, 2012[7]).

All municipalities in the region have adopted the RGS and share the goal of focusing growth strategically within a compact region in a network of centres that includes transit expansion. Transit-oriented locations are sought after for redevelopment. Therefore, Metro Vancouver has established partnerships as there is a complex web of decision-makers that need to be created to find solutions. For instance, municipalities, financial institutions and developers are responsible for housing developments; TransLink, the Mayors' Council, and senior levels of government are responsible for transit; and industry, boards of trade, and most levels of government have a role in promoting economic development. Moreover, connecting affordable housing and transit cross multiple jurisdictional borders.

Metro Vancouver, the Majors' Council and TransLink can undertake actions in partnership to advance regional housing and transport goals. For instance: Metro Vancouver's Regional Affordable Housing Strategy presents regional actions to enhance housing diversity and affordability in transit-oriented locations; TransLink's Regional Transportation Strategy includes a commitment by the regional transportation authority to encourage affordable and rental housing along the Frequent Transit Network; and the Mayors' Council vision for regional transportation is a 10-year programme to expand the Frequent Transit Network and to invest in cycling, walking, and road infrastructure. To complement the efforts for affordable housing in FTDAs local governments estimate that they still need subsidies from upper levels of government, other fiscal measures and new partnerships.

\section{Funding for transport via partnerships}

A key element to realise the accessibility vision contained in the RTS is to ensure stable, sufficient and appropriate funding that is both affordable and equitable for the region's inhabitants. TransLink has taxation authority and, since 2008, has collected the carbon tax. It receives a portion of the fuel tax and property tax for funding transport investment plans (Government of British Columbia, 1998[31]). Other sources of revenues include smaller fees. The federal government contributes with $40 \%$ of the income. Funding the 10-Year Transport vision requires CAD 7 billion (USD 5.2 billion approximately) to cover major capital investment and increases in bus services.

Finding the right mix of funding sources in the short and long term requires the creation of partnerships that should include contributions from the federal, provincial and local level governments. Major capital 
initiatives that connect the region, support the economy and create sustainable communities are also funded via partnerships. These types of projects are considered generational as they produce local, regional, provincial and national benefits in the long term. Therefore, their funding should be ensured by all levels of government. The region normally funds up to one-third of the capital costs and assumes longterm responsibility for operating and maintaining the services, whereas the national and provincial governments provide at least two-thirds of capital funding as transport infrastructure also contributes to achieving provincial and national goals.

Since local communities also benefit from major capital investments (because they generate higher land values, generate incremental tax revenue and support city building objectives), they are responsible for ensuring that formal partnerships are in place. The Mayors' Council, TransLink and host municipalities develop partnership agreements for 10-year investment plans. Any municipal financial contribution is intended to cost-share for a specific project providing both regional and local impact. Contributions may be one-time, ongoing or property contributions towards direct construction costs. Local financial contributions may take the form of in-kind contributions (Mayors'Council on Regional Transportation, 2017[15]). TransLink contributions to project investments are defined in the agreements which may include: project investment commitments (capital, operating and phasing), planning and process commitments, transportation service and system integration, and funding, etc. To update the strategies for future investments, the different municipalities coordinate the development and improvement of a regionally consistent system of monitoring, evaluation, and transparent reporting.

\section{Table 7. Strategies to build strong partnerships, ensure funding, and perform assessments}

\begin{tabular}{|c|c|}
\hline Strategy & Some key actions \\
\hline Support regional land use objectives & $\begin{array}{l}\text { - Make transport investment decisions concurrent with partner-mandated (and } \\
\text { supportive) land use decisions. } \\
\text { Establish mechanisms such as partnership agreements and joint planning to } \\
\text { provide greater certainty around expected and agreed-upon and use, policies } \\
\text { and investments. } \\
\text { Develop corridor and area plans, and provide supportive funding, to improve } \\
\text { access to and within frequent transit areas. } \\
\text { Ensure that ports, airports, gateways and industrial facilities are located in } \\
\text { - } \quad \text { areas that allow for safe and efficient regional goods movement. } \\
\text { Encourage affordable and rental housing along the Frequent Transit Network. }\end{array}$ \\
\hline $\begin{array}{l}\text { Ensure effective coordination through strong } \\
\text { partnerships }\end{array}$ & $\begin{array}{l}\text { - Convene and facilitate ongoing regional dialogue through stakeholder forums, } \\
\text { standing advisory committees, and a goods movement council. } \\
\text { Advocate for a regional economic development strategy that clearly addresses } \\
\text { transport priorities. } \\
\text { Develop strategies to ensure that a skilled and qualified labour force is } \\
\text { available to plan, build, operate and maintain the transport system. }\end{array}$ \\
\hline $\begin{array}{l}\text { Establish funding that is stable, sufficient, } \\
\text { appropriate and influences travel choices }\end{array}$ & $\begin{array}{l}\text { Transport should be priced more accurately to better align behaviour and } \\
\text { transport objectives. } \\
\text { Transit fare rates should be sensitive to public affordability. } \\
\text { - } \quad \text { funding should be generated form the goods movement sector to recognise } \\
\text { the costs } \\
\text { - The proportion of funding from property taxes should not increase. } \\
\text { - } \quad \text { Funding sources should be reliable, predictable, but also adjustable. } \\
\text { - } \quad \text { conding options should be economically efficient in their administration and } \\
\text { Advocate for regional transportation funding at the provincial and national level. }\end{array}$ \\
\hline $\begin{array}{l}\text { Monitor progress towards our desired } \\
\text { outcomes }\end{array}$ & $\begin{array}{l}\text { - Establish a robust and coordinated system of monitoring, evaluation and } \\
\text { reporting including feedback loops to adjust course as necessary. } \\
\text { Build into the funding framework the ability to adjust the mix and rates of } \\
\text { different revenue tools to respond to changes in behaviour. } \\
\text { - } \quad \text { Continuously improve data collection and evaluation tools. } \\
\text { - } \quad \text { Make transport data publicly available. }\end{array}$ \\
\hline
\end{tabular}

Source: Based on TransLink (2013[32]). 


\section{Strong community engagement underpins transport projects}

Community engagement (public participation or public involvement) is considered in the region a fundamental civic goal to create an engaged city to address issues of common importance, solve shared problems and create positive social change. This is a way for authorities to obtain people's feedback on refined content, and to listen to people's concerns and aspirations on a number of social, economic and urban development related issues. For that purpose, local authorities organise open houses, talk surveys, focus groups, workshops, and public hearings.

Community engagement is a critical component in the planning process as the formulation process of the main strategic documents, such as Official Community Plans, must involve residents. For example, the City of Richmond updated its 1999 Official Community Plan in 2009. This update was made possible with the extensive participation of residents, business owners, stakeholders (e.g. Richmond School Board, Vancouver International Airport (YVR), Port Metro Vancouver, Metro Vancouver, Urban Development Institute), community groups, and the City's advisory committees. Over the two and a half year period, the process involved three major rounds of community consultation with over 30 public open houses, city-wide surveys and online discussion forums. Similarly, separate consultation processes were conducted for the 10-Year Social Development Strategy (twelve meetings with stakeholder and advisory committee groups, one online discussion forum and four study circles) and the Parks and Open Space Strategy (seven focus groups) (City of Richmond, 2012[20]). Often, it takes years of consultations when it comes to land use, as civic engagement should be considered at different stages of planning.

MVR has a long history of civic engagement. The City of Surrey, for instance, consults at least three times with citizens at different stages of the planning process. Promoting citizens' participation in urban development issues such as land use, transport and housing requires having a good understanding of what the local or regional authority want to achieve. Authorities should be clear about whether they want to inform or gather input from the public. Likewise, to manage expectations it is important that citizens be informed, from the outset, of the objectives of the exercise. Having a good plan determines who can take part and for what reason. Once authorities receive feedback from people, when it is sought after, it is necessary to share it back with the community as a whole. Reporting back on what was heard and how it was heard is of the outmost importance to maintain credibility as normally people want to know their feedback was used. To promote citizens' participation, local governments need to go to the people as they would never or very seldom approach government with their ideas or feedback. Government has to take the initiative. The messages should be simple as people should not feel overwhelmed. The use of Information and Communication Technologies (ICTs) can facilitate the interaction between citizens and government, but online consultations should be quick (2-3 minutes) and short (4 questions maximum).

Some of the recurring themes that emerged throughout the City of Richmond's consultations were: i) provide more housing choices; ii) undertake neighbourhood shopping centre densification planning; iii) improve streets and connectivity in neighbourhoods; iv) create more parks and open spaces; v) improve transportation, transit service, and expand the cycling network across the city; vi) have more walkable and accessible neighbourhoods; and vii) improve the ecological network and its services (City of Richmond, 2012[20]). 


\section{Reinforcing MVR's accessibility strategy}

The Metro Vancouver Region has made substantial and sustained progress in fostering accessibility by implementing the transit-oriented communities approach. As Table 8 shows, MVR's main strengths are concentrated in their long-term planning capacity and capability, the coordination of different plans and strategies (i.e. transport, land-use, economic growth), the collaboration among the planning (Metro Vancouver) and transport (TransLink) authorities as well as with the different local authorities (municipalities), and the strong community engagement in local affairs. These assets have enabled MVR to design and implement a strategy that is conducive to providing better access to jobs, goods and services.

\section{Table 8. Analysing the Metro Vancouver Region’s accessibility experience}

\begin{tabular}{|c|c|}
\hline Strengths & Weaknesses \\
\hline $\begin{array}{l}\text { - Strong links among the regional growth strategy, the } 10 \text {-year } \\
\text { investment plans, and the regional transportation strategy. } \\
\text { - Long-term regional planning that reflects a vision for regional } \\
\text { development. } \\
\text { - Adoption of a transit-oriented approach that emphasises pedestrians. } \\
\text { - Alignment between transport priorities and land-use policies. } \\
\text { - Alignment between regional and local transport strategies. } \\
\text { Promotion of walking, cycling and transit to cover short distances in } \\
\text { local transport plans. } \\
\text { Affordability regarded as the sum of housing and transport costs. } \\
\text { Strong coordination between Metro Vancouver (regional planning } \\
\text { agency) and TransLink (regional transport authority), and coordination } \\
\text { with local authorities (municipalities). } \\
\text { Funding transport projects through partnerships with public, private, } \\
\text { and community organisations as well as the funding model of the } \\
\text { transport agency. } \\
\text { Strong community engagement in local affairs. } \\
\text { Strong capacity and capability in regional planning and transport } \\
\text { bodies. }\end{array}$ & $\begin{array}{l}\text { - Connectivity within and among certain municipalities, } \\
\text { particularly the largest ones is limited due to lack of } \\
\text { infrastructure and transport options. } \\
\text { - Some neighbourhoods in municipalities located farther away } \\
\text { from the urban core lack proper infrastructure for walking (i.e. } \\
\text { pavements). } \\
\text { The application of the "transit-oriented communities" strategy is } \\
\text { making housing unaffordable near transport hubs for low- } \\
\text { income households. } \\
\text { New digital technologies are underutilised for the diversification } \\
\text { of transport options. } \\
\text { Strong reliance on the fuel tax for financing transport } \\
\text { investments. } \\
\text { The lack of a smart city strategy that underpins smart mobility } \\
\text { initiatives. }\end{array}$ \\
\hline Opportunities & Threats \\
\hline $\begin{array}{l}\text { The COVID-19 pandemic may incentivise people to walk and cycle } \\
\text { more. }\end{array}$ & $\begin{array}{l}\text { Rural areas may be urbanised increasing the need for further } \\
\text { transport investments. }\end{array}$ \\
\hline
\end{tabular}


- The new digital technologies and the emergence of smart mobility initiatives could facilitate accessibility to goods and services while making better use of land and protecting the environment.

- The geographic limitations may continue to incentivise the development of a compact and connected urban development based on the transit-oriented communities approach.
Equity challenges caused by the development of transportoriented communities that make housing expensive around transport hubs.

External shocks to the economy (e.g., financial and economic crises).

- The COVID-19 pandemic may lead to a resurgence of car usage and a decrease in public transport use.

- The digital divide may prevent low-income households (e.g., immigrants) from accessing goods and services.

However, Figure 7 there are at least five main areas where action is required to make further progress on the building of transit-oriented communities: affordable housing, smart mobility, financing, building infrastructure and behavioural change.

\section{Figure 7. Proposed actions to support the MVR accessibility strategy}

\section{1) Ensure affordable housing in areas with high accessibility}

-Ensure transport services in areas outside the FTDAs.

-Adopt legal requirements to ensure that housing remains affordable in the long term when planning TOCS.

-Subsidy priority to transit-oriented developments with an affordable housing component.

-Require a complete assessment of the spillover effects of transport expansion on housing prior to project approval.

2) Adopt a smart city and smart mobility framework

- Design a specific smart mobility strategy that leverage(digital) technology innovations.

-Revise and adapt the regulatory framework to enable the use of technology for mobility.

3) Make funding for transport infrastructure more sustainable

-Explore and analyse the viability of diversifying the sources of revenue: land valuecapture schemes, development costs charges, etc.

-Incentivise private investment to improve efficiency based on a sound regulatory framework.

4) Improve the infrastructure for walking and cycling

-Build pavements (sidewalks) in all neighbourhoods, especially in those in distant locations.

-Complete the bicyclenetwork in all municipalities.

5) Use the current health emergency to promote active mobility and behaviouralchange

-Use COVID-19 as an opportunity to promote walking and cycling in areas where residents remain unconvinced.

- Use investments in active mobility infrastructure as part of the preparedness for future (i.e. health)emergencies.

-Leverage on the strong engagement community culture to find acceptable mobility alternatives.

Source: Own elaboration

The first area of action is to ensure affordable housing for low- and middle-income households in areas with access to a range of services and amenities including public transport services. Closeness to transit stations tends to raise the price of housing making it hard for low- and middle-income households to find accommodation in central areas. Metro Vancouver and TransLink may need to ensure that areas located outside the FTDAs also have access to regular transport services, which requires expanding bus services and prioritising the construction of walking and cycling infrastructure in those areas. Metro Vancouver and TransLink would need to create the incentives for long-term housing affordability when planning new public transit investments or transport-oriented communities by adopting legal requirements that ensure that 
housing remains affordable over the long term. One possible option to explore would be the introduction of subsidies for low-income households. In allocating the subsidy, priority should be given to transitoriented developments that include an affordable component and have a plan to deal with undesired spillover effects. Requiring a thorough assessment of the spillover effects of transport expansion in housing prices prior to the initiation of any project and a plan to ensure affordability would be a way forward. One particular proposal to bridge the affordable housing gap is to make federal financing for transit conditional on municipal zoning. This would ensure that sufficient affordable housing is located near new transit projects (Hyslop, 2015[29]). This proposal is called the 30/30/30 plan. Under this scheme the federal government provides $30 \%$ of the financing for a major transit project on the condition that the municipalities involved agree to pre-zone everything within a kilometre of the project. This also requires that $30 \%$ of all new housing units cost no more than $30 \%$ of the region's median income to occupy. The goal is to align housing and transit because for most households transportation is the second biggest cost (Hyslop, 2015[29]).

The second area of opportunity refers to adoption of a smart city and smart mobility framework. It would prepare and guide the region for the adoption of digital technologies to boost well-being and deliver more efficient and sustainable transport options. MVR has the conditions to design and implement a smart mobility strategy such as: planning and administrative capacity, access to data, infrastructure, and a consolidated and reliable transport network. There is no national smart city strategy that provides guidance to cities in leveraging digital technologies for mobility and accessibility. In the context of the COVID-19 pandemic, MVR may wish to explore designing a specific smart city and smart mobility strategy that leverages multiple levels of technological innovations for innovative service and use cases (i.e. on-demand van services, dynamic parking charges or robo-taxis). As a first step, Metro Vancouver and TransLink could revise and adapt the regulatory framework to enable the use of digital technology for mobility services. It is important that regulation be flexible in order to account for many unknowns around the uptake and impact of technologies and services (ITF/OECD, 2020[1]). Moreover, MVR needs to prepare its legislation, planning and infrastructure for moving to electric and automated vehicles. TransLink will explore potential policy and investment priorities to prepare for these emerging trends as part of the update to the Regional Transportation Strategy.

The third action is making the model for funding transport infrastructure projects more sustainable and less dependent on a single tax. There is a heavy reliance on fuel tax for financing transport projects despite the formation of partnerships. The current financing structure of investment projects works during boom periods. The question is what would happen when the economy slows down or the metro area shifts to electric vehicles and has a higher uptake of digital technologies for mobility. TransLink needs to explore other sources of revenue, particularly those that affect behavioural change. For instance, land value capture schemes, development cost charges or benefiting capture taxes could be considered but they should be in line with the policy goals of the provincial government (Krawchenko, 2012[7]). TransLink could also incentivise private investment in transport infrastructure to improve efficiency but it would be necessary to ensure that the right institutional and regulatory framework conditions are in place (ITF, 2018[33]).

The fourth aspect is to improve the infrastructure for walking and cycling in some municipalities. The City of Surrey, for example, needs to build pavements for some neighbourhoods that were not part of the development conditions at the time of development. The municipality is vast and the distance between residential areas and transport hubs is substantial and connectivity is limited. TransLink and local authorities are already working to solve this problem by financing the construction of pavements which are seen as encouraging active mobility. The programmes to complete the bicycle network in some municipalities need to continue.

The final area of action is to use the current health emergency as an opportunity to promote active mobility and incentivise behavioural change. The current context characterised by a decreasing use of public transport could be an opportunity to promote active mobility (walking and cycling). TransLink could take 
this opportunity to incentivise behavioural change in areas of the metropolitan areas where residents still need to be convinced about the benefits of cycling for example. It could even be an opportunity to justify the investment in cycling infrastructure in central areas of the city of Vancouver. Nevertheless, the COVID19 pandemic represents a bigger threat to regional development and the development of transit-oriented communities. The fear of contagion and social distancing are driving people away from public transport and back to their private vehicles. Certainly, the use of private cars is the safer way of moving about town in the current context but, in the long term, driving may not be sustainable. It would certainly compromise efforts to achieve environmental goals. Even if it is harder to justify planned transport investment under the transit-oriented community approach in the current context, they must be seen as an investment for the sustainability of the region, preparedness for similar crises in the future, and as a response to the current pandemic. Authorities in the MVR could leverage on the strong community engagement culture in the region to explain the need for a change on mobility patterns and finding solutions that are acceptable to larger segments of the population. As transit-oriented communities aim to facilitate the access to jobs, goods and services, provide a wide range of housing choices, and encourage active mobility, they could provide the conditions for a better response to similar pandemics and contribute to higher levels of wellbeing in an inclusive manner. 


\section{In Conclusion - what lessons can be learned from MVR on fostering accessibility?}

There are important policy lessons that have emerged from the experience of the Metro Vancouver Region in enhancing accessibility via transport investment:

- To maintain and even increase the levels of well-being and economic growth, investment in public transport is essential. Indeed, one of the key underpinnings of MVR's reputation as a region with one of the highest living standards in the world and economic growth is its investment in public transport and connectivity. Public transport has connected people to job opportunities and services while contributing to environmental objectives as it provides efficient alternatives to personal vehicles.

- Pursuing accessibility is a long-term continuous investment process. Consistency is central to the idea of developing transit-oriented communities. The key is to maintain the vision for regional development over time and that requires political commitment and citizens' engagement. The OECD Principles on Urban Policy indeed suggest that a strategy to build smart, sustainable, and inclusive cities is essential to set a clear vision for urban policy assessing and addressing the challenges posed by the socio-economic local context (OECD, 2019[34]). All actors should share the same view on how they want their city/region to evolve. That vision should be reflected in the key strategic planning documents of the metropolitan area both at regional and local level.

- Local development planning, land use planning, and transport policy need to work in a coordinated fashion based on a regional/metropolitan approach. The experience of Metro Vancouver shows that to build transport-oriented communities there should be sound strategic planning that guides land use, transportation, housing, environmental, economic and social policy decisions. Moreover, transport policy by itself will not have the desired impact in terms of accessibility and sustainability unless it is coordinated with other policies notably housing, environmental protection, and economic development. In the Metro Vancouver Region, transport (RTS), economic growth, and land use (RGS) planning are inextricably linked and this is necessary to ensure that urban and regional development is both sound and balanced. Furthermore, the MVR's experience shows that in metropolitan areas - composed of different administrative units planning should be conducted at a regional or metropolitan level to ensure coherent investment decisions and provide guidance to local level decisions. This is in line with the OECD Principles on Urban Policy that call for an adaptation of policy action to the place where people live and work by adapting development strategies and public service delivery to the diversity of urban scales (OECD, 2019[34]). In the MVR, regional economic and transport plans influence the Official 
Community Plans formulated at local level, which must state how they will contribute to regional objectives while meeting local needs.

- Building transport-oriented communities requires giving pedestrians the highest priority over any other means of transportation. In the MVR, after a long period of focusing solely on road construction, now when transport investment decisions are made officials ask how such decisions will promote or affect walking and cycling. This assumes that people can have access to jobs, schools and public services within short distances and this is what Metro Vancouver has prioritised through land use policies that favour mixed-land uses. It is therefore important incentivise people to shift from driving to active mobility such as good quality pavements and streets, security and risk-free cycling infrastructure. Cities in MVR have even established a hierarchy (pedestrians, bicycles, transit, cars) that guides decision-making and promotes a shift in transportation patterns.

- Prioritising densification along transit corridors is beneficial for long-term urban sustainability. By allocating resources to the creation of successful TODs, public acceptance of more sustainable urban forms is increased, especially given that concerns regarding neighbourhood character preservation often run high in single-family districts.

- Housing affordability and public transport need to be considered in tandem to improve quality of life, competitiveness and productivity in cities. Housing developments in locations without good connectivity have limited access to goods and services. However, if transport investments are made without taking into consideration how housing can remain affordable, it may in turn make housing expensive for low-income households. The experience of the Metro Vancouver Region shows that approaching affordability by analysing housing and transport together may be a way forward. This approach provides a more comprehensive view of affordability by looking not just at the price of housing (buying or renting) but location and expenditure on transport as well. The problem is to strike a balance. Considerations need to be given to maintaining affordability when expanding the transport network or building closer to transport hubs.

- The creation of a regional body for coordinating the transport strategy. Since the creation of TransLink transport services have expanded considerably along with capital infrastructure, budgets, scope and capacities. Service hours have increased dramatically from 3190 service hours in 1997 to 515000 service hours in 2009 (Krawchenko, 2012[7]). Having a central transport body with formal powers and funding to formulate and coordinate the implementation of transport plans across the region is a way to reduce the cost of administrative fragmentation (Ahrend, Lembcke and Schumann, 2016[35]; OECD, 2015[36]). TransLink is also a very cooperative institution that works closely with its partners to facilitate the alignment of transport policies with other regional development policies. Its governance structure, which empowers the Mayors' Council with high level policy decisions and the corporate board for operational issues, makes it more accountable to the public and facilitates efficiency. TransLink's case also shows the importance of ensuring a stable source of funding and the need to adapt those sources of revenue in a way that i) ensures long-term funding for investment projects, ii) is considered fair for local governments and iii) changes people's behaviour, to a certain extent, towards mobility means. An additional point is that the close coordination between the transport authority (TransLink) and the regional planning authority (Metro Vancouver) allow for coherence in planning and decision-making under a comprehensive regional approach.

- The creation of partnerships among different actors may facilitate policy-making, and financing for implementation. Getting governance right in a metropolitan area is not always easy. Yet, the experience of the Metro Vancouver Region shows that creating a formal partnership for policy-making and funding of investment projects is a way forward. The partnerships seem to facilitate coordination, establish funding that is stable, sufficient and appropriate, and since there is a wide range of actors partnerships ensure that they all work in support of the regional growth 
and land use objectives. Although Metro Vancouver and TransLink are separate entities they work in coordination which can be evidenced by the fact that the RGS and the RTS are highly linked. TransLink alone would not be able to ensure the success of accessibility and affordable housing in the Metro Vancouver Region. The success rests in the coordination and joint work that TransLink conducts with Metro Vancouver (regional planning) and all municipalities in the region in the development, implementation and assessment of the Metro Vancouver Regional Growth Strategy. Perhaps the one problem is that Metro Vancouver and TransLink and their respective plans have different timelines. In addition, the Metro Vancouver experience shows the need for sound political leadership at the regional level that is highly professional. Metro Vancouver and its council board are an example of that. Metro Vancouver conducts specialised regional planning and its activities are backed by the council, which includes the mayors of the different member municipalities.

- The success of transport projects and land use plans require a high level of civic engagement. In line with the OECD Principles on Urban Policy, the experience of the Metro Vancouver Region shows that effective citizen engagement can yield a number of benefits, including: building trust in government; generating better outcomes; securing higher compliance levels with decisions reached; enhancing equity of access to public policy-making and services; leveraging knowledge and resources; and developing innovative solutions. For citizen participation to be productive, governments must share the agenda-setting power and commit to taking into account policy proposals generated jointly with citizens. 


\section{References}

Ahrend, R., A. Lembcke and A. Schumann (2016), Why metropolitan governance matters a lot more than you think, https://voxeu.org/article/why-metropolitan-governance-matters (accessed on 23 September 2020).

Black, I. (2018), 2018 Greater Vancouver Economic Scorecard, Greater Vancouver Board of Trade, https://www.boardoftrade.com/files/advocacy/2018-local-election/briefingpresentations/votelocal-scorecard-2018-presentation.pdf (accessed on 19 March 2020).

City of New Westminster (2014), New Westminster Master Transortation Plan, https://www.newwestcity.ca/council minutes/0616 14/2014-0611\%20New\%20West\%20Master\%20Transportation\%20Plan\%20DRAFT.pdf.

City of Richmond (2012), City of Richmond BC - Bylaw 9000 - 2041 Official Community Plan (OCP) Schedule 1, https://www.richmond.ca/cityhall/bylaws/ocp/sched1.htm (accessed on 13 September 2018).

City of Richmond (2012), City of Richmond BC - Bylaw 9000 - 2041 Official Community Plan (OCP) Schedule 1, https://www.richmond.ca/cityhall/bylaws/ocp/sched1.htm (accessed on 13 September 2018).

City Of Vancouver (2017), Economic Structure of Vancouver: GDP of Metro Vancouver, City of Vancouver, Vancouver.

Coquitlam City (2017), Citywide Official Community Plan, Community Plans, http://www.coquitlam.ca/planning-and-development/community-plans/community-plans.aspx (accessed on 27 August 2018).

Government of British Columbia (1998), South Coast British Columbia Transportation Authority Act, http://www.bclaws.ca/civix/document/id/complete/statreg/98030 01\#section25 (accessed on 19 March 2020).

Hyslop, K. (2015), One Big Idea to Tie Affordable Housing to Accessible Transit, https://thetyee.ca/News/2015/12/08/Affordable-Housing-Accessible-Transit/ (accessed on 25 June 2018).

Ipsos (2017), 2017 Citizen Survey, City of Coquitlam, Final Report, Ipsos Public Affairs, City of Coquitlam, https://www.coquitlam.ca/docs/default-source/city-hallfiles/2017 ipsos reid citizen satisfaction survey - full report.pdf.

ITF (2018), Private Investment in Transport Infrastructure Dealing with Uncertainty in Contracts, International Transport Forum, http://www.itf-oecd.org (accessed on 18 November 2020).

ITF/OECD (2020), Leveraging digital technology and data for human-centric smart cities: The case of smart mobility, http://www.oecd.org/termsandconditions. (accessed on 29 July 2020). 
Krawchenko, T. (2012), Institutional solutions to jurisdictional fragmentation: the implications of regional special purpose bodies for how city-regions are governed in Canada, Carleton University, Ottawa, https://curve.carleton.ca/system/files/etd/e7394189-ce9c-4ab8-86390e8d4757f3cc/etd pdf/f61957f28474c73272213bd880d940b6/krawchenkoinstitutionalsolutionstojurisdictionalfragmentation.pdf.

Mayors'Council on Regional Transportation (2017), Regional Transportation Investments a Vision for Metro Vancouver, https://tenyearvision.translink.ca/downloads/10\%20Year\%20Vision\%20for\%20Metro\%20Van couver\%20Transit\%20and\%20Transportation.pdf (accessed on 29 March 2018).

McElhanney (2018), 2017 Vancouver Transportation Panel Survey Report - Finalized Draft, https://vancouver.ca/files/cov/2017-transportation-panel-survey-final-draft-20180516.pdf (accessed on 28 August 2018).

Metro Vancouver (2019), Transit-Oriented Affordable Housing Study - Executive Summary, http://www.metrovancouver.org/services/regional-planning/PlanningPublications/TransitOrientedAffordableHousingStudyPhase2.pdf (accessed on 19 March 2020).

Metro Vancouver (2015), The Metro Vancouver housing and transportation cost burden study - a new way of looking at affordability, Metro Vancouver, Vancouver, http://www.metrovancouver.org/services/regionalplanning/PlanningPublications/HousingAndTransportCostBurdenReport2015.pdf (accessed on 29 June 2018).

Metro Vancouver (1976), The Livable Region 1976/1986. Proposals to Manage the Growth of Greater Vancouver, Metro Vancouver, Vancouver, http://www.metrovancouver.org/about/library/LibraryPublications/Livable Region 19761986 - Proposals to Manage the Growth of Greater Vancouver.pdf (accessed on 17 January 2019).

Metro Vancouver Regional District (2011), Regional Growth Strategy - Metro Vancouver 2040: Shaping Our Future, http://www.metrovancouver.org/services/regionalplanning/PlanningPublications/RGSAdoptedbyGVRDBoard.pdf (accessed on 5 April 2018).

MetroVancouver (2017), Transit-Oriented Affordable Housing Study, http://www.metrovancouver.org/services/regional-planning/housing-affordability/transitoriented/Pages/default.aspx (accessed on 25 June 2018).

MUSTEL Group and Halcrow (2010), TransLink's 2008 Regional Trip Diary Survey: Final Report, http://www.mustelgroup.com (accessed on 29 August 2018).

Ngo, V. (2012), "Identifying areas for transit-oriented development in Vancouver using GIS", Trail Six: An Undergraduate Journal of Geography, pp. 91-102.

OECD (2020), City Policy Responses, OECD , Paris, https://read.oecdilibrary.org/view/?ref=126 126769-yen45847kf\&title=Coronavirus-COVID-19-Cities-PolicyResponses.

OECD (2019), OECD Principles on Urban Policy, OECD, Paris, http://www.oecd.org/cfe/ (accessed on 16 March 2020). 
OECD (2015), Governing the City, OECD, http://www.oecd-

ilibrary.org/docserver/download/0415011e.pdf?expires $=1502295601$ \&id=id\&accname=ocid84 004878\&checksum $=750$ EDAF3B05050DD6197E7742F6C69D1 (accessed on

9 August 2017).

OECD (2012), Compact City Policies: A Comparative Assessment, OECD Green Growth

Studies, OECD Publishing, Paris, https://dx.doi.org/10.1787/9789264167865-en.

The Conference Board of Canada (2016), Greater Vancouver Economic Scorecard 2016, The Conference Board of Canada, Vancouver, https://www.boardoftrade.com/scorecard2016/files/Full\%20Report\%20\%20Greater\%20Vancouver\%20Economic\%20Scorecard\%202016.pdf (accessed on 13 April 2018).

TransLink (2018), 10-Year Vision - progress on delivering phase one, https://tenyearvision.translink.ca/downloads/Phase1Progress final.pdf (accessed on 29 March 2018).

TransLink (2018), Metro Vancouver Leads Canada and the US in Transit Ridership Growth, https://www.translink.ca/About-Us/Media/2018/March/Metro-Vancouver-Leads-Canada-andthe-US-in-Transit-Ridership-Growth.aspx (accessed on 17 January 2019).

TransLink (2018), Phase Two of the 10-Year Vision. 20182027 Investment Plan, https://tenyearvision.translink.ca/Documents/10-year vision phase 2 investment plan.pdf (accessed on 17 January 2019).

TransLink (2013), 2011 Metro Vancouver Regional Trip Diary Survey Analysis Report, TransLink, Vancouver, https://www.translink.ca//media/Documents/customer info/translink listens/customer surveys/trip diaries/2011Metro-Vancouver-Regional-Trip-Diary--Analysis-Report.pdf (accessed on 17 January 2019).

TransLink (2013), REGIONAL TRANSPORTATION STRATEGY Strategic Framework A mESSAGE FROm ThE BOARd ChAIR, TransLink, Vancouver, https://www.translink.ca//media/Documents/plans and projects/regional transportation strategy/rts strategic framew ork 0731 2013.pdf?la=en\&hash=0A459174FB44A8870D00EFCE54124A01078D0698 (accessed on 29 March 2018).

TransLink (2013), REGIONAL TRANSPORTATION STRATEGY Strategic Framework A Message from the Board Chair, TransLink, Vancouver, https://www.translink.ca//media/Documents/plans and projects/regional transportation strategy/rts strategic framew ork 0731 2013.pdf?la=en\&hash=0A459174FB44A8870D00EFCE54124A01078D0698 (accessed on 29 March 2018).

TransLink (2012), Transit-Oriented Communities Design Guidelines Creating more livable places around transit in Metro Vancouver, https://www.translink.ca/ /media/documents/plans and projects/transit oriented communitie s/transit oriented communities design guidelines.ashx (accessed on 28 August 2018).

TransLink (n.d.), TransLink Sustainability Policy - creating a more sustainable future, TransLink, Vancouver, http://cst.uwinnipeg.ca/documents/Defining Sustainable 2005.pdf (accessed on 13 April 2018). 
Vancouver Foundation (2016), Home - Vital Signs, http://vancouverfoundationvitalsigns.ca/ (accessed on 14 January 2019).

Vivideconomics (2020), Green Stimulus Index, https://www.vivideconomics.com/wpcontent/uploads/2020/07/GreenStimulusIndex14July.pdf (accessed on 7 October 2020).

World Economic Forum (2019), Making Affordable Housing a Reality in Cities, http://www.weforum.org (accessed on 14 January 2020).

Yuen, C. (2018), Why Does Ridership Rise or Fall? Lessons from Canada - Human Transit, Human Transit, https://humantransit.org/2018/04/why-does-ridership-rise-or-fall-lessons-fromcanada.html (accessed on 17 January 2019).

\section{Notes}

1 For further information see: TriCity News https://www.tricitynews.com/news/how-will-the-covid-19pandemic-affect-public-transit-long-term-1.24140224

${ }^{2}$ For further information see: Mustel Group: https://mustelgroup.com/covid-19-the-future-of-transit-inmetro-vancouver-uncertain/

${ }^{3}$ For further information see: https://canada.constructconnect.com/dcn/news/economic/2020/06/expectteleworking-to-complement-not-replace-the-traditional-office

4 For further information see: Statistics Canada, Census Profile, 2016 Census http://www12.statcan.gc.ca/census-recensement/2016/dp-

$\mathrm{pd} /$ prof/details/page.cfm?Lang=E\&Geo1=CD\&Code1=5915\&Geo2=PR\&Code2=47\&Data=Count\&Searc

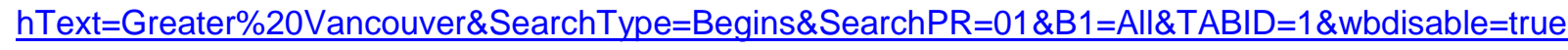

${ }^{5}$ For further information see: https://tenyearvision.translink.ca/faq

${ }^{6}$ For further information see: www.coquitlam.ca/planning-and-development/community-plans/communityplans.aspx

${ }^{7}$ See for example Coquitlam Citywide Official Community Plan (Coquitlam City, 2017[21])

8 For further information on Vancouver as one the best cities to live in the world see: https://www.telegraph.co.uk/travel/galleries/The-worlds-most-liveable-cities/vancouver/;

https://www.cntraveler.com/gallery/the-most-livable-cities-in-the-world;

http://www.businessinsider.fr/us/best-cities-in-the-world-mercer-2018-quality-of-living-index-2018-3

${ }^{9}$ For further information see: https://www.translink.ca/Schedules-and-Maps/SkyTrain.aspx

${ }^{10}$ The BC Climate Action Plan aims to reduce GHG emissions by $33 \%$ by 2020 and by $80 \%$ by 2050 , from 2007 levels.

${ }^{11}$ Information gathered during the interviews conducted in the City of Vancouver for the elaboration of this case study. 
${ }^{12}$ Affordable housing is typically defined as housing that costs less than $30 \%$ of a household's pre-tax income. By this definition, a household earning CAD 50000 can afford rent that does not exceed approximately CAD 1300 per month.

13 For further information see: http://www.metrovancouver.org/services/regional-planning/housingaffordability/transit-oriented/Pages/default.aspx

${ }^{14}$ For further information see: www.metrovancouver.org/about/Pages/default.aspx. 
More information: oecd.org/regional/

Follow us on Twitter:

y @OECD_local 